Supporting Information for

\title{
Enzymatically Forming Intranuclear Peptide Assemblies for Selectively Killing Human Induced Pluripotent Stem Cells
}

Shuang Liu, ${ }^{\dagger}, \xi$ Qiuxin Zhang, ${ }^{\dagger}$ Adrianna N. Shy, ${ }^{\dagger}$ Meihui Yi, ${ }^{\dagger}$ Hongjian He,${ }^{\dagger}$ Shijiang Lu, ${ }^{\ddagger}$ Bing $\mathrm{Xu}^{*}, \dagger$

'Department of Chemistry, Brandeis University, 415 South Street, Waltham, Massachusetts, 02454, United States

${ }^{\xi}$ School of Materials Science and Engineering, Wuhan University of Technology, 122 Luoshi Road, Wuhan, Hubei, 430070, China

*HebeCell, 21 Strathmore Road, Natick, Massachusetts, 01760, United States

Content

S1. Materials and instruments

S2. Synthesis and characterization of the precursors

S3. TEM sample preparation

S4. Critical micelle concentration (CMC) measurement

S5. Dephosphorylation rate measurement

S6. Cell culture

S7. Differentiation of human iPSC to iPS-derived Hematopoietic Progenitor Cells (HPCs)

S8. Cell viability

S9. Confocal laser scanning microscopy (CLSM) imaging

S10. Degradation

S11. Supporting data 


\section{S1. Materials and instruments}

2-Cl-trityl chloride resin (1.0-1.2 mmol/g), HOBt, HBTU, Fmoc-OSu, and other Fmoc-amino acids were purchased from GL Biochem (Shanghai, China). Other chemical reagents and solvents were purchased from Fisher Scientific. Alkaline phosphatase was purchased from Biomatik (Cat. No. A1130, Alkaline Phosphatase [ALP], $30000 \mathrm{U} / \mathrm{mL}$, in 50\% Glycerol.), Fetal bovine serum (FBS) and penicillin-streptomycin were purchased from Gibco by Life Technologies. All precursors were purified with Agilent 1100 Series Liquid Chromatograph system, equipped with an XTerra C18 RP column and Variable Wavelength Detector. The LC-MS spectra were obtained with a Waters Acquity Ultra Performance LC with Waters MICROMASS detector, and ${ }^{1}$ HNMR spectra on Varian Unity Inova 400. Circular dichroism (CD) spectra were obtained with a Jasco J-810 Spectropolarimeter. UV-Vis spectra were obtained with a Varian Cary 50 Bio UV-Visible Spectrophotometer.

\section{S2. Synthesis and characterization of the precursors}

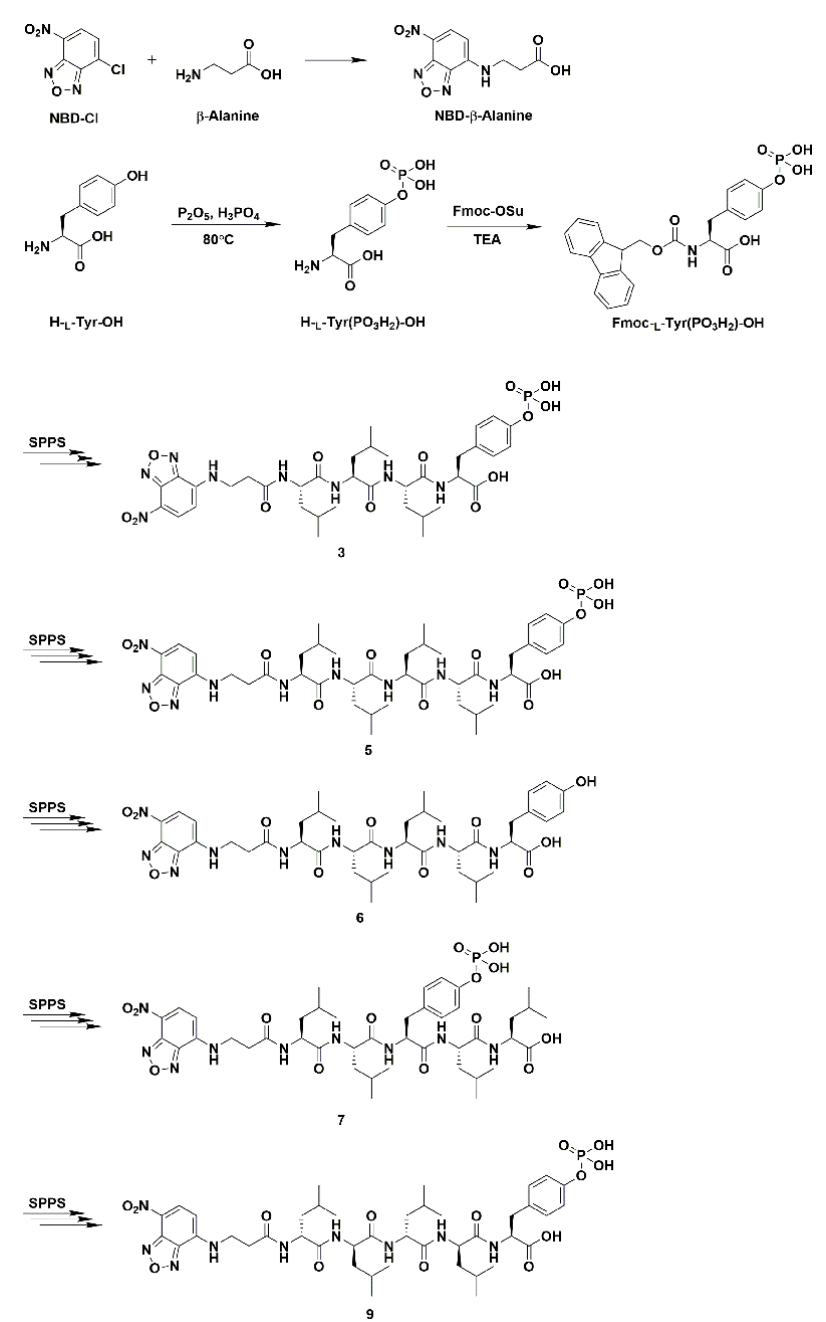

Scheme S1. Synthetic route of 3, 5, 6, 7 and 9. 


\section{Synthesis of NBD-ק-alanine}

To the solution of $\beta$-Alanine ( $5 \mathrm{mmol}, 1 \mathrm{~g}$ ) and $\mathrm{K}_{2} \mathrm{CO}_{3}(15 \mathrm{mmol}, 2 \mathrm{~g})$ in $\mathrm{H}_{2} \mathrm{O}(15 \mathrm{~mL})$, the solution of $\mathrm{NBD}-\mathrm{Cl}$ in $\mathrm{MeOH}(30 \mathrm{~mL})$ was added dropwise under the protection of $\mathrm{N}_{2}$. After reaction at room temperature for $3 \mathrm{~h}$, the $\mathrm{MeOH}$ was removed by evaporation. After adding $70 \mathrm{~mL} \mathrm{H}_{2} \mathrm{O}$, the $\mathrm{pH}$ was the solution was adjusted by $1 \mathrm{M} \mathrm{HCl}$ to $\sim 3$. The solution was extracted by diethyl ether $(200 \mathrm{~mL} \times 3)$, and the organic part was dried by $\mathrm{Na}_{2} \mathrm{SO}_{4}$, filtered and concentrated by evaporation. ${ }^{1} \mathrm{H}$ NMR of NBD- $\beta$-Alanine (400 MHz, $\left.\mathrm{CD}_{3} \mathrm{OD}-\mathrm{d}_{4}\right) \delta(\mathrm{ppm}): 8.55$ (m, $\left.1 \mathrm{H}\right), 6.40(\mathrm{~d}, 1 \mathrm{H}), 3.82(\mathrm{~s}$, 2H), 2.79 (t, 2H). MS: calc. [M-H] $]^{-}=251.04$, obsvd. ESI-MS: M/Z $=250.95$.

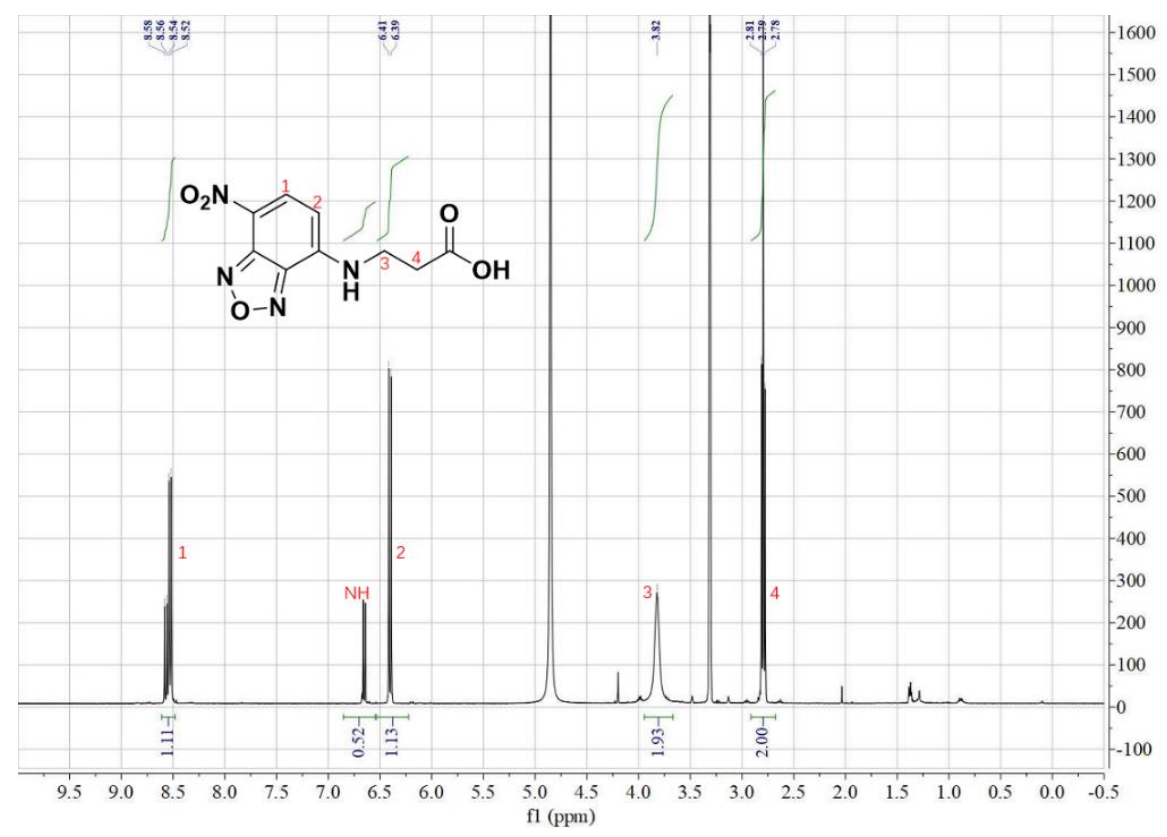

Figure S1. ${ }^{1} \mathrm{H}$ NMR spectrum of NBD- $\beta$-alanine.

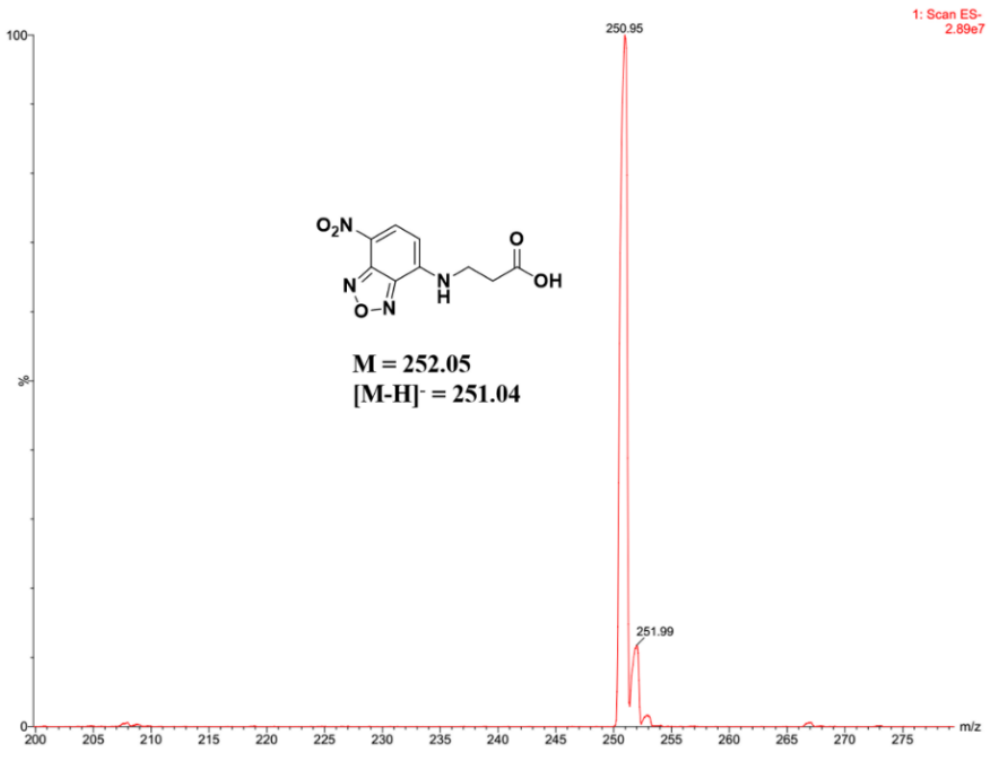

Figure S2. Mass spectrum of NBD- $\beta$-Alanine $(M / Z=250.95)$. 


\section{Synthesis of Fmoc- - -Tyr $\left(\mathrm{PO}_{3} \underline{\mathrm{H}}_{2}\right)-\mathrm{OH}$}

The mixture of $\mathrm{P}_{2} \mathrm{O}_{5}(35 \mathrm{mmol}, 10 \mathrm{~g}), \mathrm{H}_{3} \mathrm{PO}_{4}(133 \mathrm{mmol}, 13 \mathrm{~g})$ and $\mathrm{H}-\mathrm{L}-\mathrm{Tyr}-\mathrm{OH}(18 \mathrm{mmol}, 3.22 \mathrm{~g})$ was stirred for $24 \mathrm{~h}$ at $80^{\circ} \mathrm{C}$ in $\mathrm{N}_{2}$ atmosphere. After adding $30 \mathrm{~mL} \mathrm{H}_{2} \mathrm{O}$ and stirred for $30 \mathrm{~min}$ at $80^{\circ} \mathrm{C}$, the reaction mixture was cool to room temperature. The reaction mixture was added to butanol $(650 \mathrm{~mL})$ dropwise and recrystallized at $4^{\circ} \mathrm{C}$ overnight, filtration provided $\mathrm{H}-\mathrm{L}-\mathrm{Tyr}\left(\mathrm{PO}_{3} \mathrm{H}_{2}\right)-\mathrm{OH}$ as white power. To the solution of $\mathrm{H}-\mathrm{L}-\mathrm{Tyr}\left(\mathrm{PO}_{3} \mathrm{H}_{2}\right)-\mathrm{OH}(2 \mathrm{mmol}, 522 \mathrm{mg})$ in $\mathrm{H}_{2} \mathrm{O}(20 \mathrm{~mL})$, the solution of Fmoc-OSu (2.4 mmol, $808 \mathrm{mg}$ ) in $\mathrm{MeCN}(20 \mathrm{~mL})$ was added. After adjusting $\mathrm{pH}$ to $\sim 8$ by triethylamine (TEA), the solution was stirred at room temperature for $2 \mathrm{~h}$. After removal of MeCN by evaporation, $60 \mathrm{~mL} \mathrm{H}_{2} \mathrm{O}$ was added and the $\mathrm{pH}$ of the solution was adjusted to $\sim 3$ by $1 \mathrm{M} \mathrm{HCl}$. After extraction by ethyl acetate $(100 \mathrm{~mL} \times 3)$, the organic part was washed by $1 \mathrm{M} \mathrm{HCl}(100 \mathrm{~mL} \times$ 2) and brine $(100 \mathrm{~mL} \times 1)$. After being dried by $\mathrm{Na}_{2} \mathrm{SO}_{4}$, filtered and concentrated by evaporation, Fmoc-L-Tyr $\left(\mathrm{PO}_{3} \mathrm{H}_{2}\right)-\mathrm{OH}$ was provided as white powder.

\section{Synthesis of $3,5,6,7$ and 9}

3, 5, 7 and $\mathbf{9}$ were synthesized by solid phase peptide synthesis with 2-Cl-trityl chloride resin, FmocL-Tyr $\left(\mathrm{PO}_{3} \mathrm{H}_{2}\right)-\mathrm{OH}$, Fmoc-L-Tyr(tBu)-OH, Fmoc-L-Leu-OH, Fmoc-D-Leu-OH, NBD- $\beta$-alanine, HOBt and HBTU. Purification with HPLC provided 3, 5, 6, 7 and $\mathbf{9}$ as yellow power.

MS of 3: calc. $[\mathrm{M}-\mathrm{H}]^{-}=833.32$, obsvd. ESI-MS: $\mathrm{M} / \mathrm{Z}=833.61$.

${ }^{1} \mathrm{H}$ NMR of 5 (400 MHz, DMSO-d 6 ) $\delta$ (ppm): 7.77 (d, 1H, J = 12 Hz), 7.14 (d, 2H, J = 8 Hz), 7.04 $(\mathrm{d}, 2 \mathrm{H}, \mathrm{J}=8 \mathrm{~Hz}), 6.45(\mathrm{~d}, 1 \mathrm{H}, \mathrm{J}=8 \mathrm{~Hz}), 4.36(\mathrm{~m}, 1 \mathrm{H}), 4.28(\mathrm{~m}, 4 \mathrm{H}), 2.98(\mathrm{~m}, 2 \mathrm{H}), 2.86(\mathrm{~m}, 2 \mathrm{H})$, $2.61(\mathrm{~m}, 2 \mathrm{H}), 1.54(\mathrm{~m}, 3 \mathrm{H}), 1.41(\mathrm{~m}, 8 \mathrm{H}), 1.25(\mathrm{~m}, 1 \mathrm{H}), 0.79(\mathrm{~m}, 24 \mathrm{H})$. MS of 5: calc. $[\mathrm{M}-\mathrm{H}]^{-}=$ 946.41, obsvd. ESI-MS: M/Z = 946.63.

MS of 6: calc. $[\mathrm{M}-\mathrm{H}]^{-}=866.44$, obsvd. ESI-MS: $\mathrm{M} / \mathrm{Z}=866.52$.

${ }^{1} \mathrm{H}$ NMR of 7 (400 MHz, DMSO-d 6 ) $\delta(\mathrm{ppm}): 7.72(\mathrm{~d}, 1 \mathrm{H}, \mathrm{J}=12 \mathrm{~Hz}), 7.08(\mathrm{~d}, 2 \mathrm{H}, \mathrm{J}=8 \mathrm{~Hz}), 7.02$ $(\mathrm{d}, 2 \mathrm{H}, \mathrm{J}=8 \mathrm{~Hz}), 6.44(\mathrm{~d}, 1 \mathrm{H}, \mathrm{J}=12 \mathrm{~Hz}), 4.36(\mathrm{~m}, 1 \mathrm{H}), 4.28(\mathrm{~m}, 4 \mathrm{H}), 2.98(\mathrm{~m}, 2 \mathrm{H}), 2.80(\mathrm{~m}, 2 \mathrm{H})$, $2.62(\mathrm{~m}, 2 \mathrm{H}), 1.52(\mathrm{~m}, 2 \mathrm{H}), 1.39(\mathrm{~m}, 8 \mathrm{H}), 1.24(\mathrm{~m}, 2 \mathrm{H}), 0.79(\mathrm{~m}, 24 \mathrm{H}) . \mathrm{MS}$ of 7: calc. $[\mathrm{M}-\mathrm{H}]^{-}=$ 946.41, obsvd. ESI-MS: M/Z = 946.60.

${ }^{1} \mathrm{H}$ NMR of 9 (400 MHz, DMSO-d 6 ) $\delta$ (ppm): 7.75 (m, 1H), 7.12 (d, 2H, J = 8 Hz), 7.00 (d, 2H, J = $8 \mathrm{~Hz}), 6.44$ (d, 1H, J = 8 Hz), 4.46 (m, 1H), 4.23 (m, 4H), 2.98 (m, 2H), 2.75 (m, 2H), 2.61 (m, 2H), $1.48(\mathrm{~m}, 12 \mathrm{H}), 0.81(\mathrm{~m}, 24 \mathrm{H}) . \mathrm{MS}$ of 9: calc. $[\mathrm{M}-\mathrm{H}]^{-}=946.41$, obsvd. ESI-MS: M/Z = 946.53. 


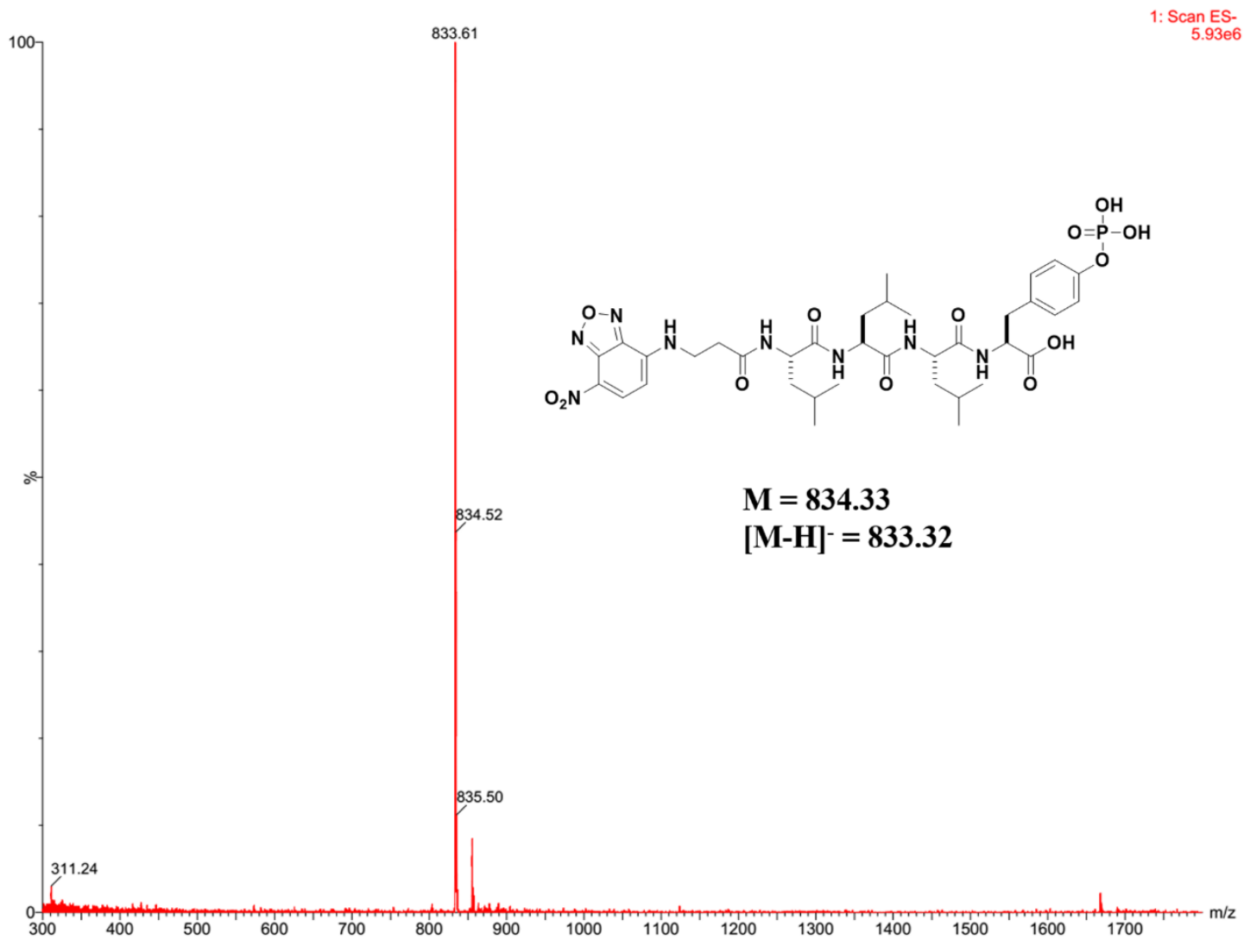

Figure S3. Mass spectrum of $3(\mathrm{M} / \mathrm{Z}=833.61)$.

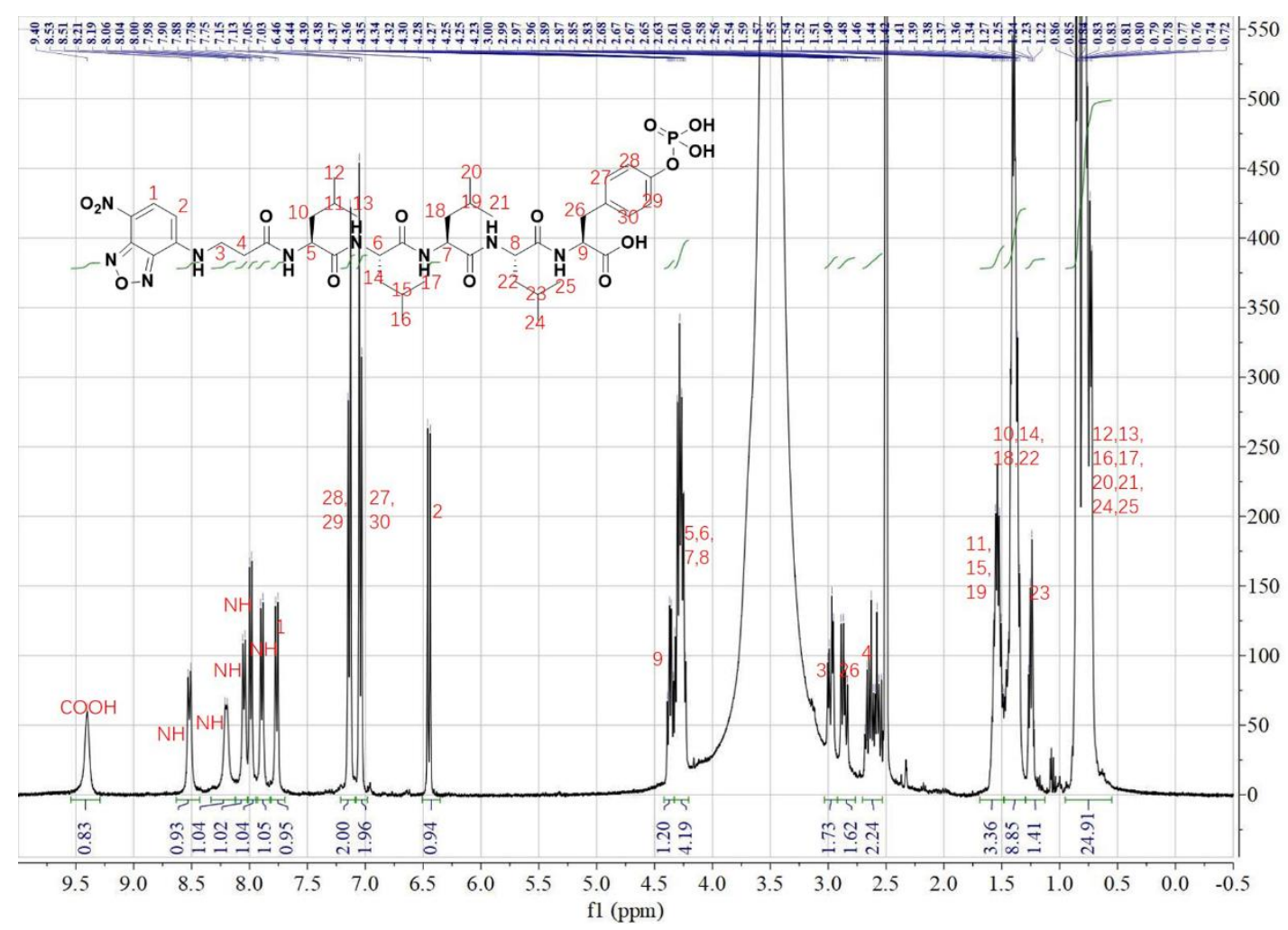

Figure S4. ${ }^{1} \mathrm{H}$ NMR spectrum of 5. 


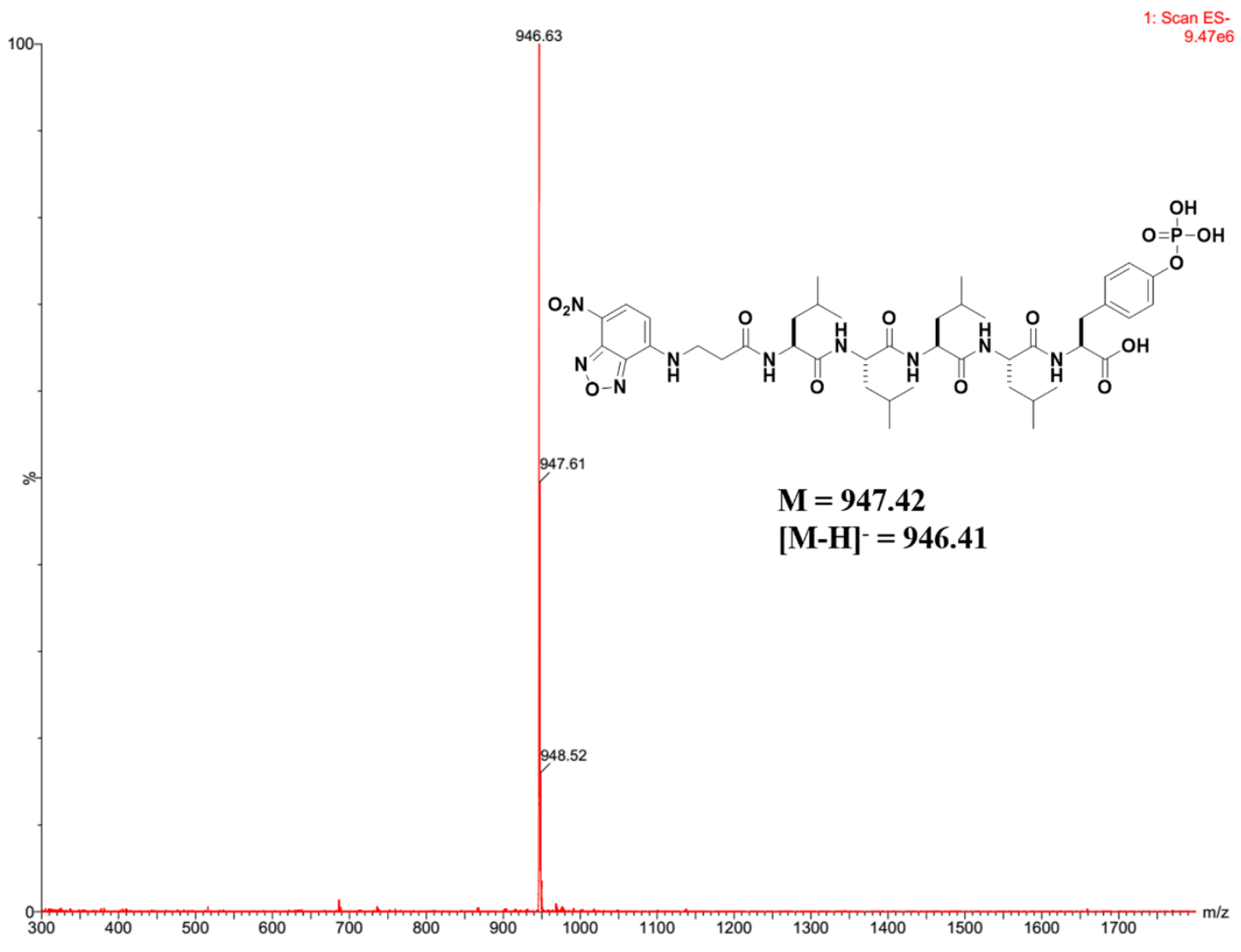

Figure S5. Mass spectrum of $5(\mathrm{M} / \mathrm{Z}=$ 946.63).

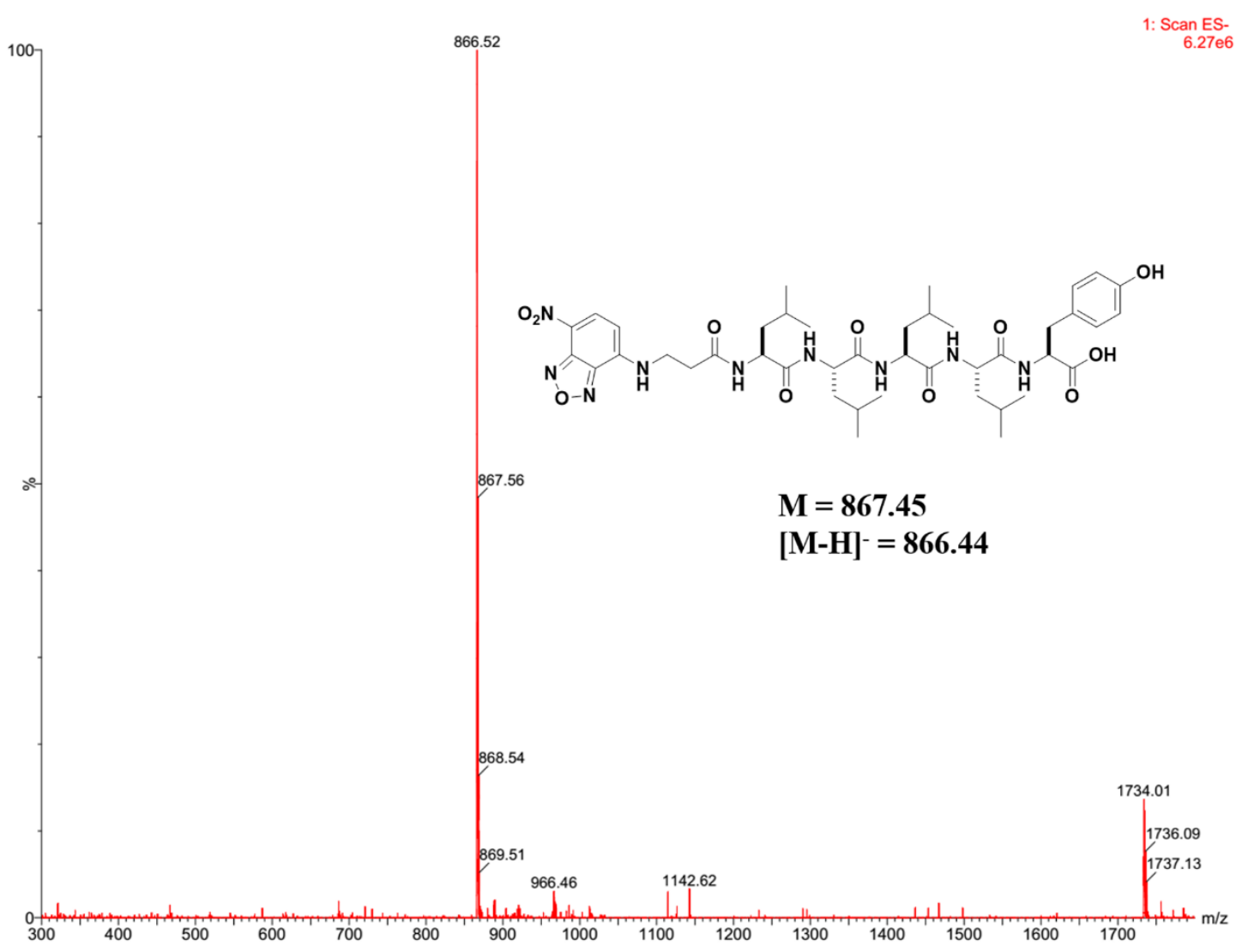

Figure S6. Mass spectrum of $6(\mathrm{M} / \mathrm{Z}=866.52)$. 


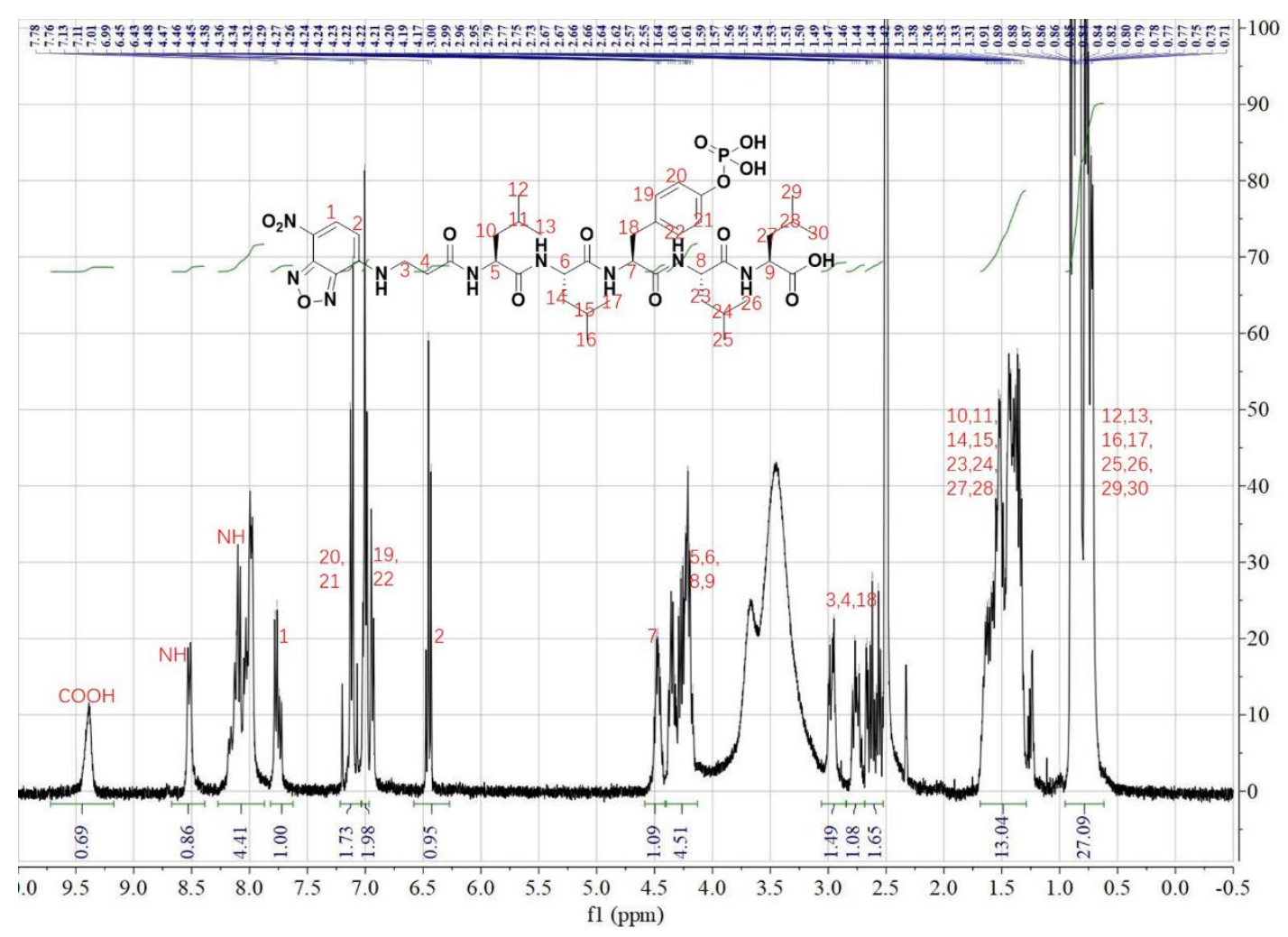

Figure S7. ${ }^{1} \mathrm{H}$ NMR spectrum of 7.

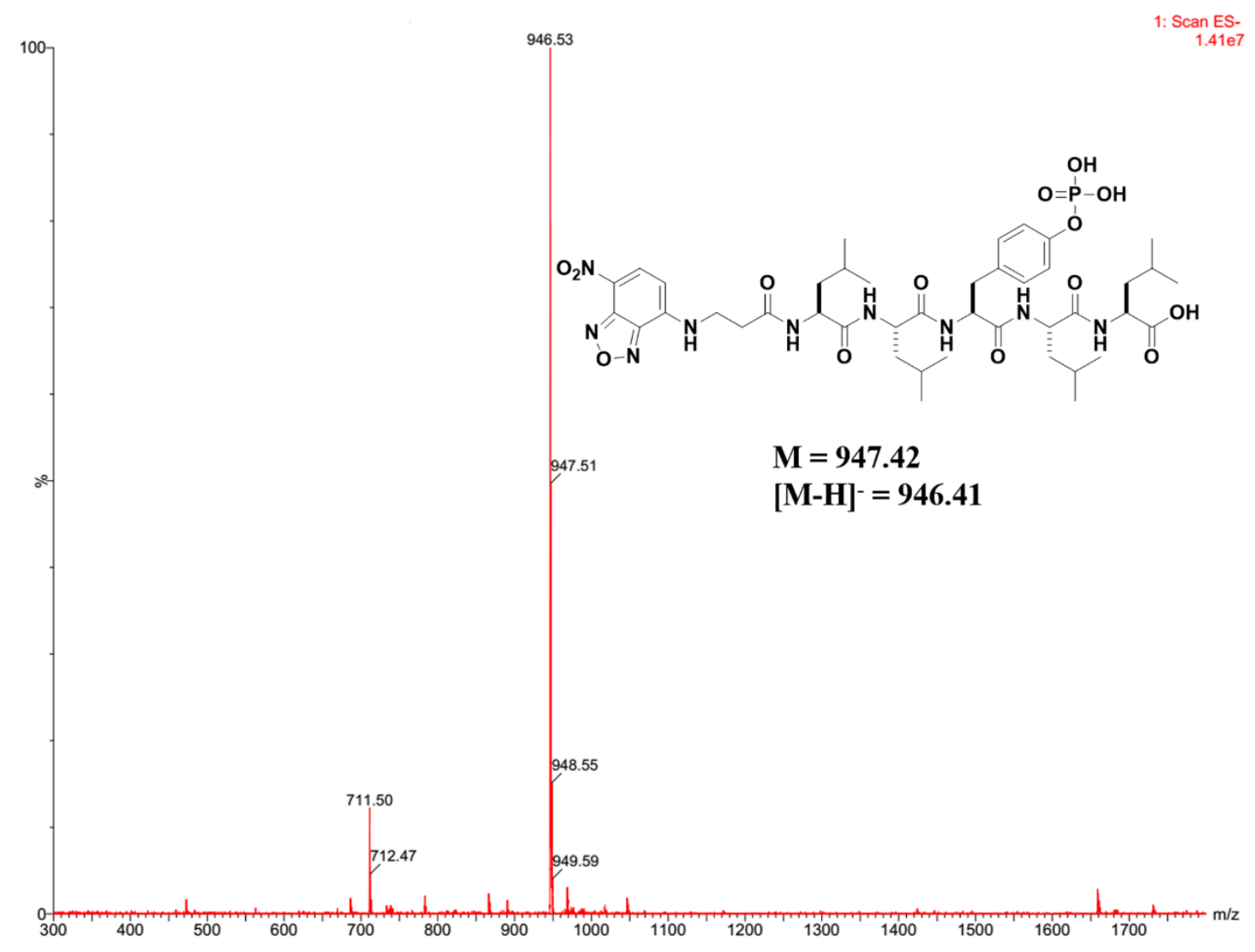

Figure S8. Mass spectrum of $7(\mathrm{M} / \mathrm{Z}=946.53)$. 


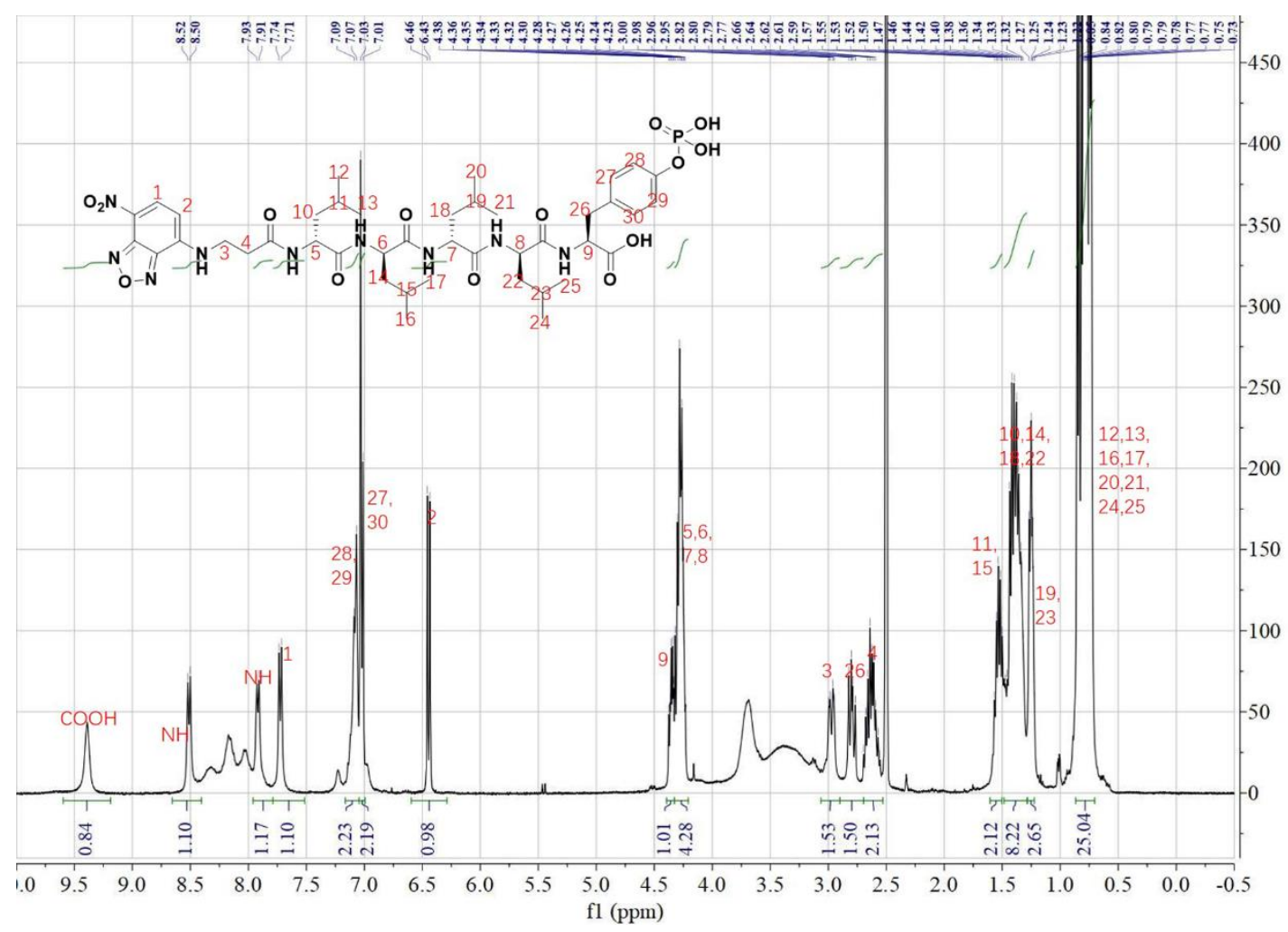

Figure S9. ${ }^{1} \mathrm{H}$ NMR spectrum of 9.

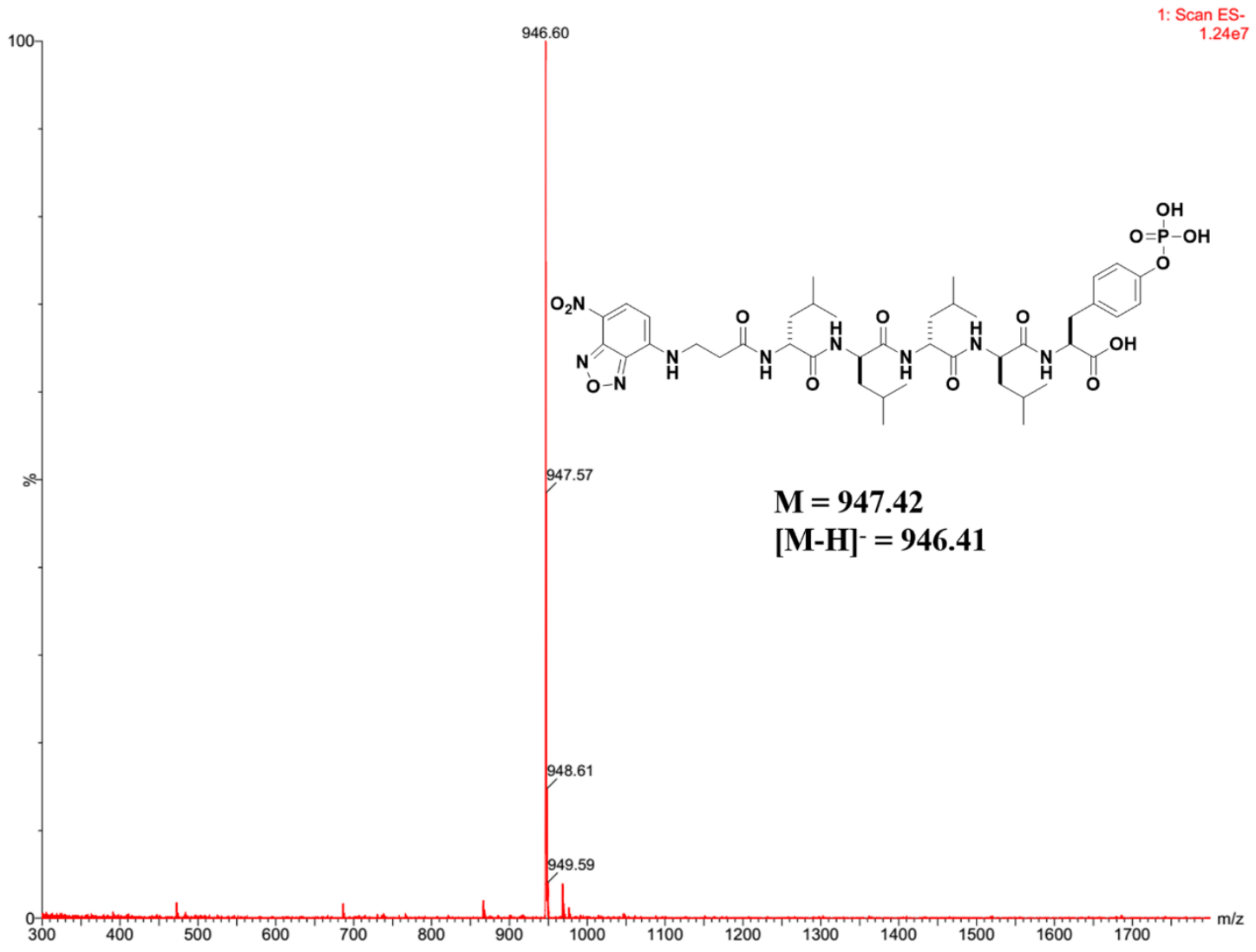

Figure S10. Mass spectrum of $9(\mathrm{M} / \mathrm{Z}=946.60)$. 


\section{S3. TEM sample preparation}

After placing $5 \mu \mathrm{L}$ samples on 400 mesh copper grids coated with continuous thick carbon film ( $\sim 35 \mathrm{~nm}$ ) which is glowed discharged, we washed the grid with $\mathrm{ddH}_{2} \mathrm{O}$ and UA (uranyl acetate). The sample loaded grid was stained with the UA. The residual UA was removed by filter paper and then dried in air. TEM images were obtained with Morgagni 268 transmission electron microscope.

\section{S4. Critical micelle concentration (CMC) measurement}

The CMCs were determined using pyrene as the fluorescent probe. Different concentrations of compounds were prepared in pyrene-saturate solutions. The fluorescence spectra of pyrene solutions with different concentration compounds were obtained. The intensity ratio of $378 \mathrm{~nm} / 393 \mathrm{~nm}$ ( $\left.\mathrm{I}_{378} / \mathrm{I}_{393}\right)$ was determined by a Synergy $\mathrm{H} 1$ hybrid multi-mode microplate reader. Plot $\mathrm{I}_{378} / \mathrm{I}_{393}$ against the concentrations of compounds. The concentration at the turning point is the CMC.

\section{S5. Dephosphorylation rate measurement}

To $100 \mu \mathrm{L}$ solution of 5,7 or 9 in PBS, ALP was added, and the mixtures were shaken at $37^{\circ} \mathrm{C}$. At different time point, $900 \mu \mathrm{L}$ methanol was added to quench the enzyme reaction. The reaction mixtures were analyzed with LC-MS.

\section{S6. Cell culture}

Human induced pluripotent stem cell line A21 was generated from human normal dermal fibroblasts by using the StemRNATM-NM Reprogramming kit (Stemgent, Cat \# 00-0076). hiPSCs were routinely cultured and passaged on 6-well plates coated with $0.25 \mu \mathrm{g} / \mathrm{cm}^{2}$ iMatrix-511 (Recombinant Laminin-511) (ReproCell) with NutriStem XF/FFTM medium (Biological Industries). HS-5 cell line and HEK293 cell line were purchased from American Type Culture Collection (ATCC, USA). HS-5 cells were cultured in Dulbecco's Modified Eagle Medium (DMEM) supplemented with 10\% fetal bovine serum (FBS), $100 \mathrm{U} / \mathrm{mL}$ penicillin and $100 \mu \mathrm{g} / \mathrm{mL}$ streptomycin. HEK293 cells were cultured in Minimal Essential Medium (MEM) supplemented with 10\% fetal bovine serum (FBS), $100 \mathrm{U} / \mathrm{mL}$ penicillin and $100 \mu \mathrm{g} / \mathrm{mL}$ streptomycin. All cells were maintained at $37^{\circ} \mathrm{C}$ in a humidified atmosphere of $5 \% \mathrm{CO}_{2}$. 


\section{S7. Differentiation of human iPSC to iPS-derived hematopoietic progenitor cells (HPCs)}

iPSCs were differentiated into hemopoietic progenitor cells (HPCs) by using a 3D-bioreactor platform ${ }^{1}$. HPCs released from iPSC-spheroids after 9-10 days' differentiation were collected and characterized. Hematopoietic lineage specific marker expression of harvested HPCs were analyzed by flow cytometry. About $97.6 \%$ of these HPCs were CD31+CD43+ double positive, but only about $13 \%$ are OCT4+, indicative of commitment to hematopoietic lineage (Figure S20). These iPSderived HPCs were used for 5 (400 uM, 2hr) cytotoxicity assay.

\section{S8. Cell viability}

iPSCs were plated in 6-well plates and incubated for 24 to 48 hours, then media were replaced with fresh one ( $2 \mathrm{ml}$ ) supplemented with PBS (control) $5(200 \mu \mathrm{M}, 300 \mu \mathrm{M}$, and $400 \mu \mathrm{M}), 7(400 \mu \mathrm{M})$ or $9(400 \mu \mathrm{M})$, and incubated for 2 hours. Media were removed and cells were rinsed with PBS once, fresh normal cultural media were added and incubated for $30 \mathrm{~min}$. All cells were collected and stained with trypan blue, live cells were counted using Cellometer Auto 2000 (Nexcelom Bioscience). Data were obtained by from three independent wells $(n=3)$.

iPS-derived HPCs were plated in 12-well plates and incubated overnight, then media were replaced with fresh one ( $2 \mathrm{ml})$ supplemented with PBS (control) $5(400 \mu \mathrm{M})$ incubated for 2 hours. All cells were collected and stained with trypan blue, live cells were counted using Cellometer Auto 2000 (Nexcelom Bioscience). Data were obtained by from three independent wells $(\mathrm{n}=3)$.

We determined the cytotoxicity against HS-5 cells and HEK293 cells by using MTT assay. Cells were seeded in 96 -well plates at $1 \times 10^{5}$ cells/well for 24 hours followed by culture medium removal and subsequently addition of culture medium containing different concentration of 5 (immediately diluted from fresh prepared $10 \mathrm{mM}$ stock solution). After 1/2/3 hours, the culture medium with 5 was replaced by fresh culture medium and $10 \mu \mathrm{L}$ MTT solution $(5 \mathrm{mg} / \mathrm{mL})$ was added to each well and incubated at $37^{\circ} \mathrm{C}$ for another $4 \mathrm{~h}$. Then $100 \mu \mathrm{L}$ of SDS-HCl solution was added to stop the reduction reaction and dissolve the formazan. The absorbance of each well at $595 \mathrm{~nm}$ was measured by a DTX880 Multimode Detector. The results were calculated as cell viability percentage relative to untreated cells. Data were obtained by from three independent wells $(n=3)$. 


\section{S9. Confocal laser scanning microscopy (CLSM) imaging}

For live cell imaging, cells in exponential growth phase were seeded in a confocal dish $(3.5 \mathrm{~cm})$ at $1.0 \times 10^{5}$ cells per dish and then incubated in incubator for $24 \mathrm{~h}$. We removed culture medium, and added fresh medium containing precursors for different time points. After removing the medium and washing the cells with live cell imaging solution $(2 \mathrm{~mL} \times 2)$, the cells were used for CLSM imaging.

For time-dependent live cell imaging, cells in exponential growth phase were seeded in a confocal dish $(3.5 \mathrm{~cm})$ at $1.0 \times 10^{5}$ cells per dish and then incubated in incubator for $24 \mathrm{~h}$. After removing culture medium, we treated the cells with $1 \mathrm{~mL}$ of Hoechst $33342(1 \mu \mathrm{g} \mathrm{mL}-1)$ for 10 minutes. After being washed with culture medium $(2 \mathrm{~mL} \times 2)$, the cells were incubated with fresh medium containing precursor $\mathbf{5}$ in a Tokai Hit stage top incubator (STXF-WSKMX-SET) to be used for CLSM imaging.

All the CLSM images were obtained using Zeiss LSM 880 confocal microscopy at the lens of $63 \times$ with oil. The lasers used are $405 \mathrm{~nm}$ and $488 \mathrm{~nm}$.

\section{S10. Degradation}

5 million HS- 5 cells were made into $1 \mathrm{~mL}$ lysate by freeze-thaw lysis method. To $100 \mu \mathrm{L}$ lysate, $\mathbf{5}$ $(200 \mu \mathrm{M})$ and rhodamine $6 \mathrm{G}$ (inner standard) were added. The mixtures were shaken at $37^{\circ} \mathrm{C}$. At different time point, $900 \mu \mathrm{L}$ methanol was added to quench the reaction. The reaction mixtures were analyzed with LC-MS. 
S11. Supporting data

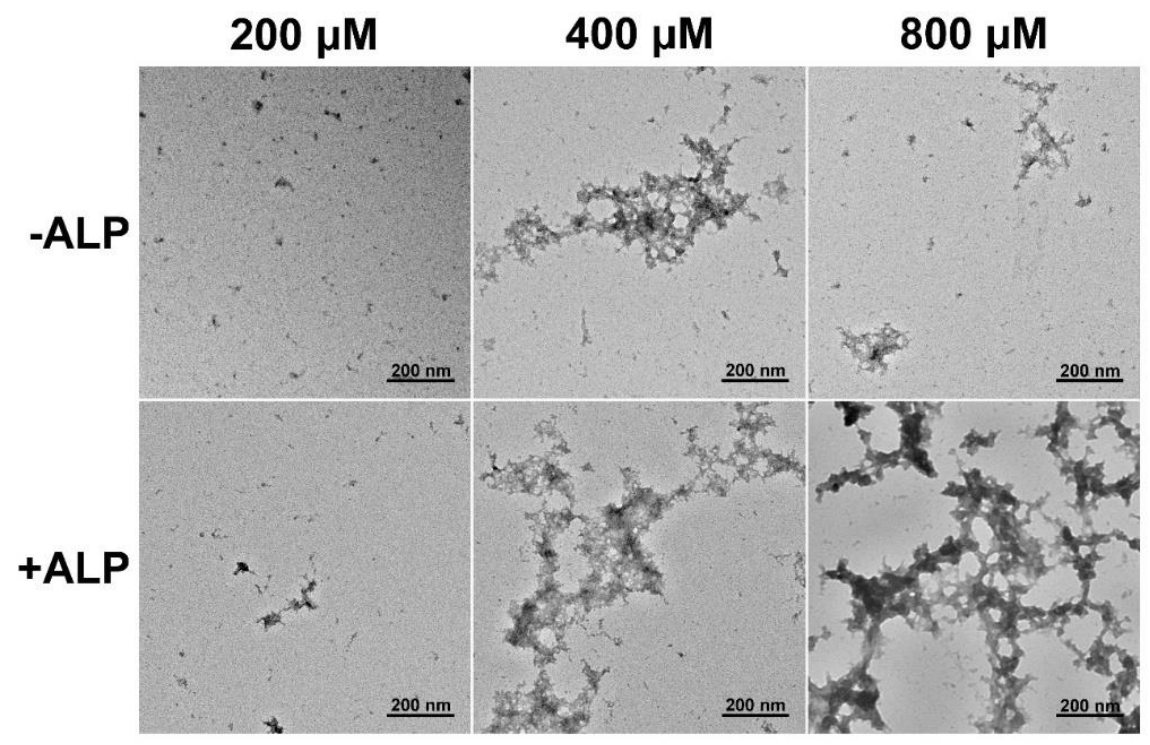

Figure S11. Transmission electron microscopes (TEM) images of $\mathbf{3}$ (200, 400, and $800 \mu \mathrm{M}$, PBS) before and after dephosphorylation by ALP $(0.5 \mathrm{U} / \mathrm{mL})$ for $24 \mathrm{~h}$.

A
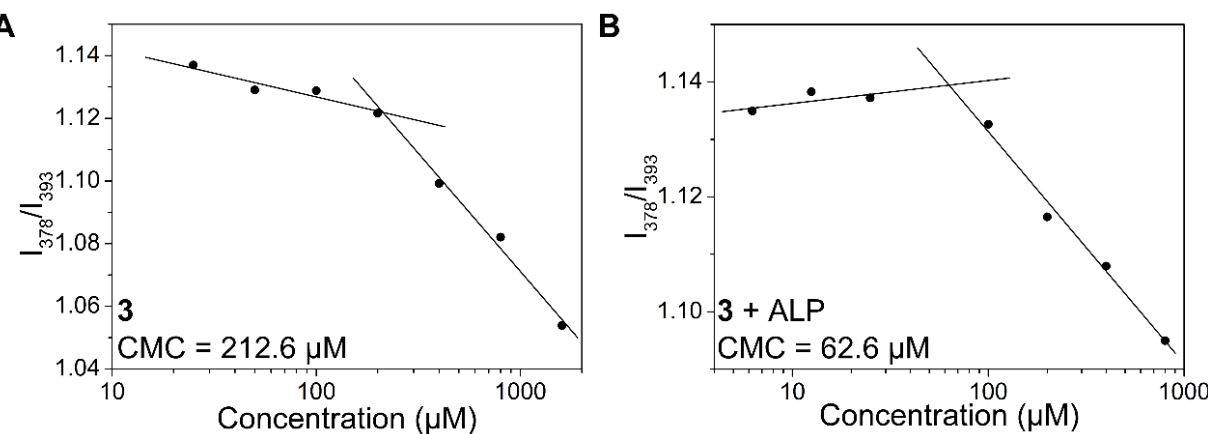

Figure S12. Critical micelle concentration (CMC) of (A) 3 and (B) $3+$ ALP $\left(0.5 \mathrm{U} / \mathrm{mL}, 37^{\circ} \mathrm{C}, 24\right.$ h). 

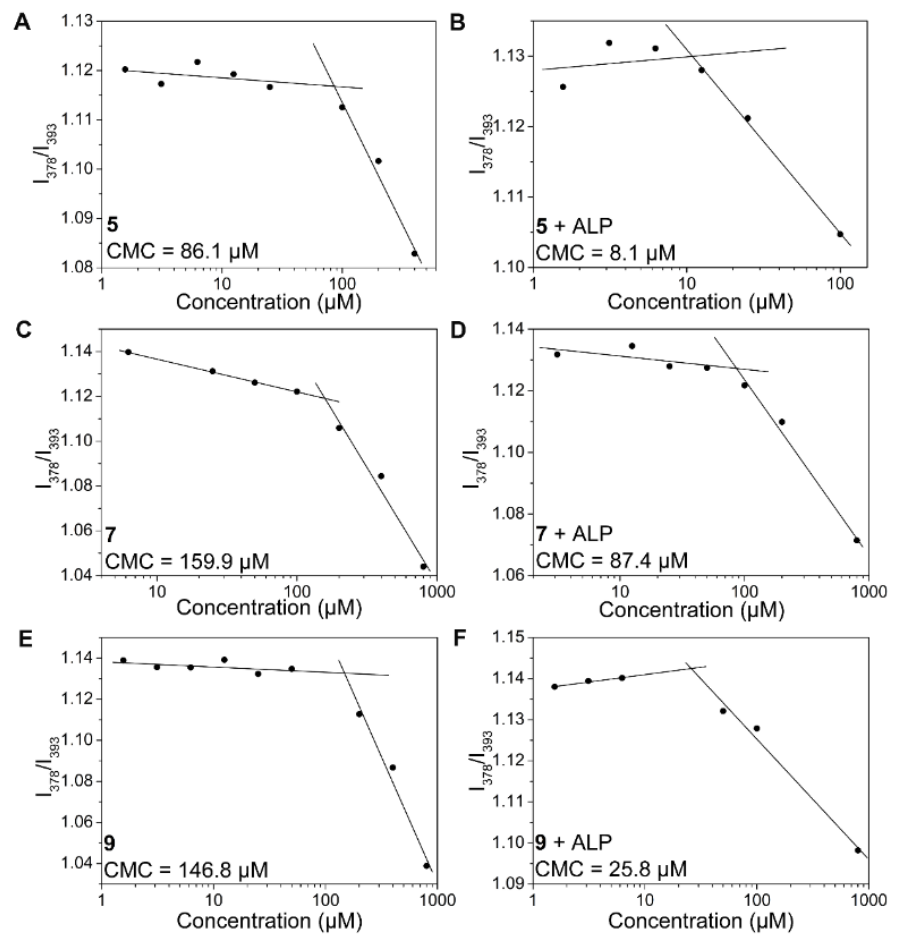

Figure S13. Critical micelle concentration (CMC) of (A) 5 (PBS), (B) 5 + ALP, (C) 7 (PBS), (D) 7 + ALP, (E) 9 (PBS) and (F) $9+$ ALP. ALP concentration is $0.5 \mathrm{U} / \mathrm{mL}\left(\mathrm{PBS}, 37^{\circ} \mathrm{C}, 24 \mathrm{~h}\right)$.

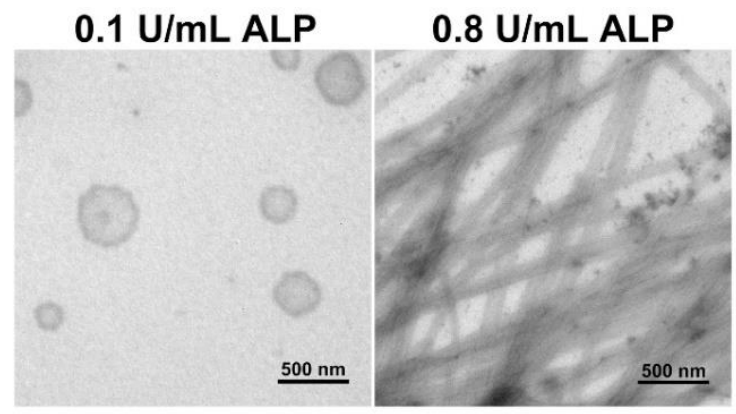

Figure S14. Transmission electron microscopes (TEM) images of 5 (200 $\mu \mathrm{M}$, PBS) after dephosphorylation by ALP $(0.1 \mathrm{U} / \mathrm{mL}$ or $0.8 \mathrm{U} / \mathrm{mL})$ for $1 \mathrm{~h}$. 


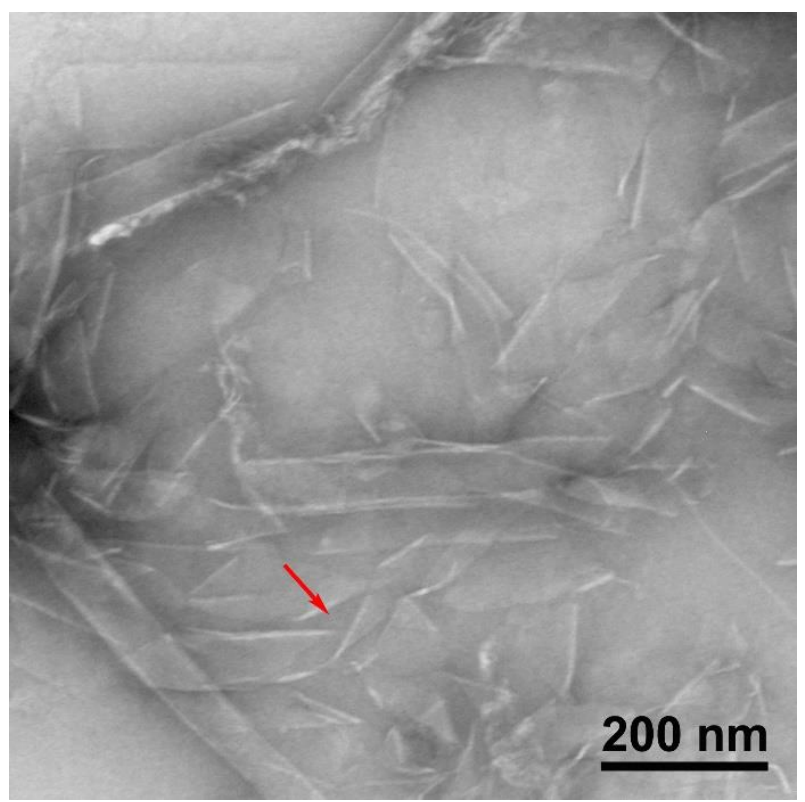

Figure S15. Transmission electron microscopes (TEM) image of 5 (400 $\mu \mathrm{M}$, PBS) after dephosphorylation by ALP $0.8 \mathrm{U} / \mathrm{mL}$ for $2 \mathrm{~h}$. The red arrow shows the folding of nanoribbons, indicating that the self-assembly nanostructures are more like nanoribbons than nanotubes.

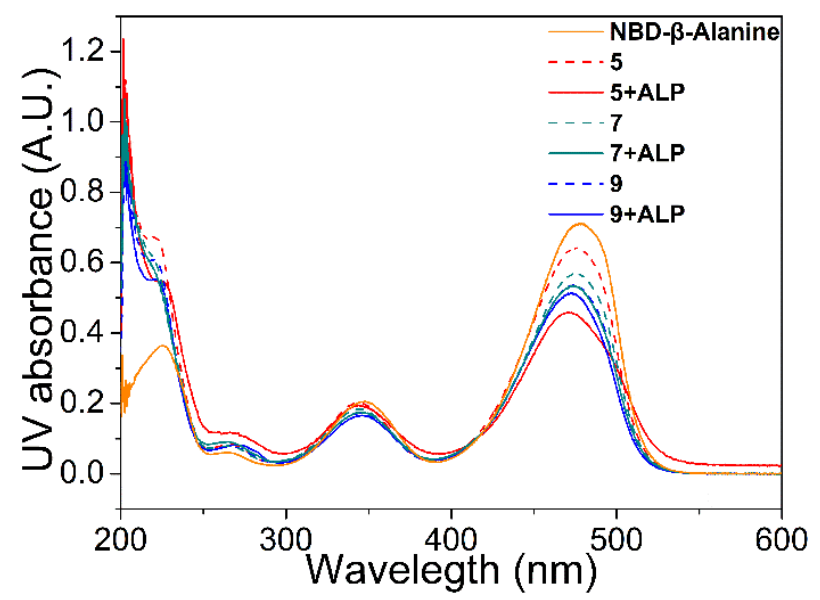

Figure S16. UV spectra of NBD- $\beta$-alanine, 5, 7 and 9 (25 $\mu \mathrm{M}$, PBS) before and after dephosphorylation by ALP $\left(0.5 \mathrm{U} / \mathrm{mL}, 37^{\circ} \mathrm{C}, 24 \mathrm{~h}\right)$. 


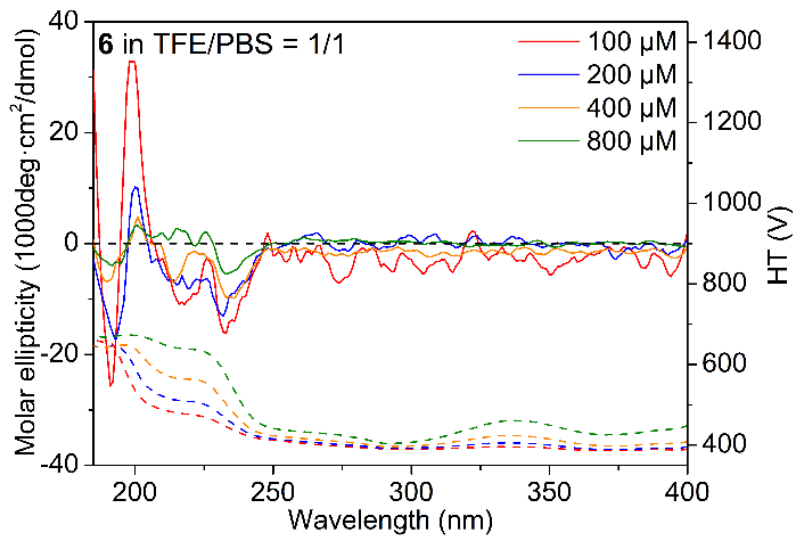

Figure S17. Circular dichroism (CD) spectra (solid line) and HT voltages (dash line) of 6 in $\mathrm{TFE} / \mathrm{PBS}=1 / 1$
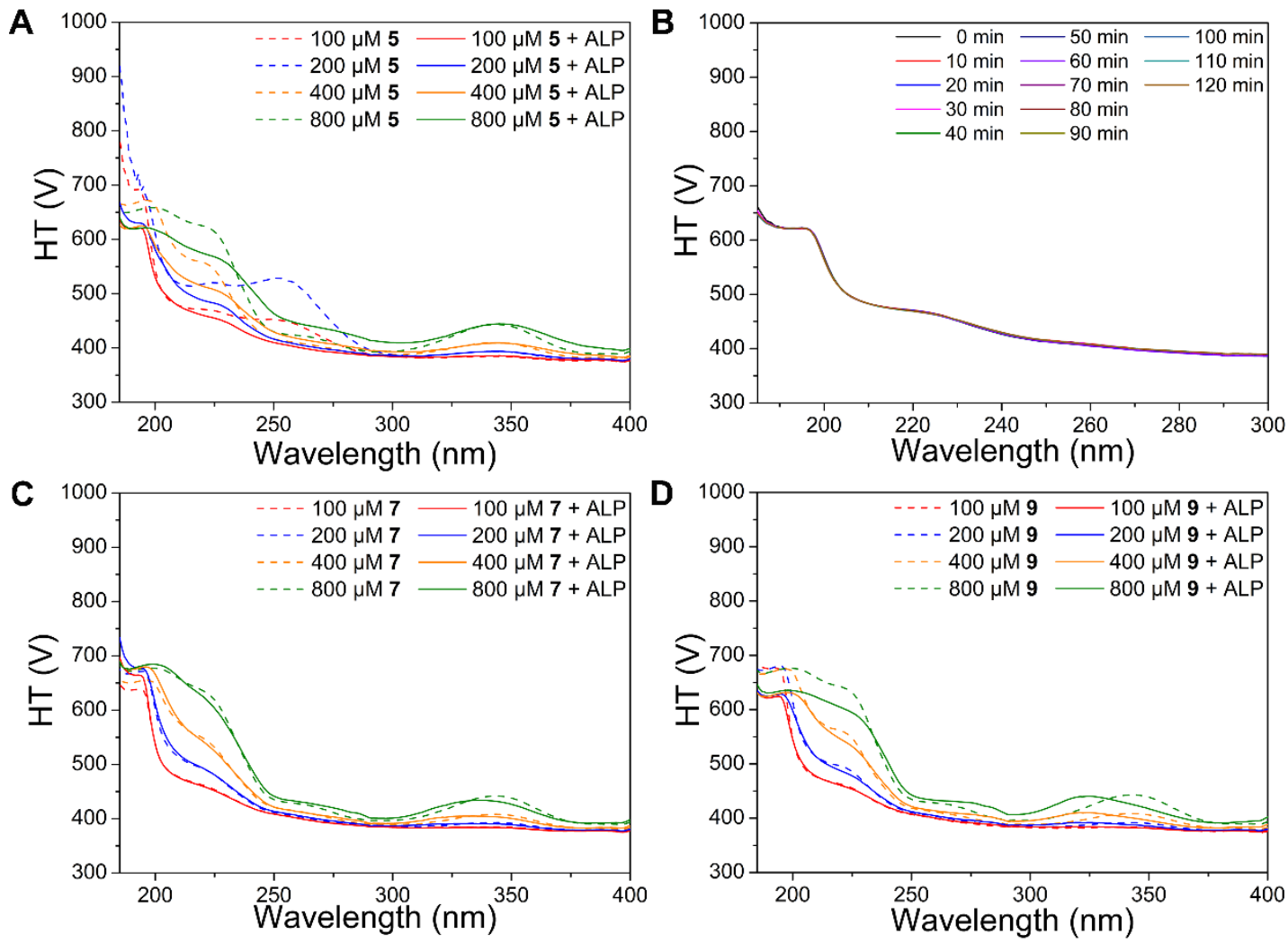

Figure S18. HT voltages of CD spectra (A) Figure 6A, (B) Figure 6B, (C) Figure 7A, and (D) Figure $7 \mathrm{~B}$. 


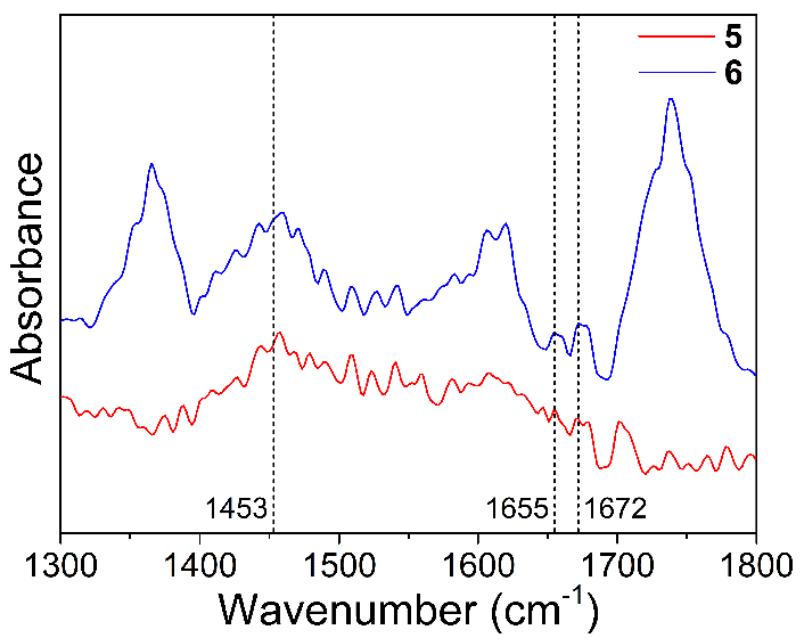

Figure S19. Fourier-transform infrared (FTIR) spectra for $20 \mathrm{mM} 5$ and 6 in $\mathrm{D}_{2} \mathrm{O}$.

Table S1. iPSC number after treatment of $5(200 \mu \mathrm{M}, 300 \mu \mathrm{M}, 400 \mu \mathrm{M})$ for $2 \mathrm{~h}$

\begin{tabular}{|c|c|c|c|c|c|c|c|c|c|c|c|c|}
\hline $\begin{array}{c}\text { Concentration } \\
\text { of 5 }\end{array}$ & \multicolumn{3}{|c|}{ Ctrl } & \multicolumn{3}{c|}{$200 \mu \mathrm{M}$} & \multicolumn{3}{c|}{$300 \mu \mathrm{M}$} & \multicolumn{3}{c|}{$400 \mu \mathrm{M}$} \\
\hline $\begin{array}{c}\text { Cell No. } \\
\left(\times 10^{4}\right)\end{array}$ & 76.4 & 66.6 & 70.5 & 24.7 & 20.5 & 21.1 & 13.4 & 12.0 & 14.1 & 4.24 & 4.26 & 6.36 \\
\hline
\end{tabular}

Table S2. iPSC number after treatment of 7, $9(400 \mu \mathrm{M})$ for $2 \mathrm{~h}$

\begin{tabular}{|c|c|c|c|c|c|c|c|c|c|}
\hline Compounds & \multicolumn{3}{|c|}{ Ctrl } & \multicolumn{3}{c|}{7} & \multicolumn{3}{c|}{9} \\
\hline Cell No. $\left(\times 10^{4}\right)$ & 72 & 114 & 108 & 97 & 119 & 98 & 101 & 100 & 88 \\
\hline
\end{tabular}
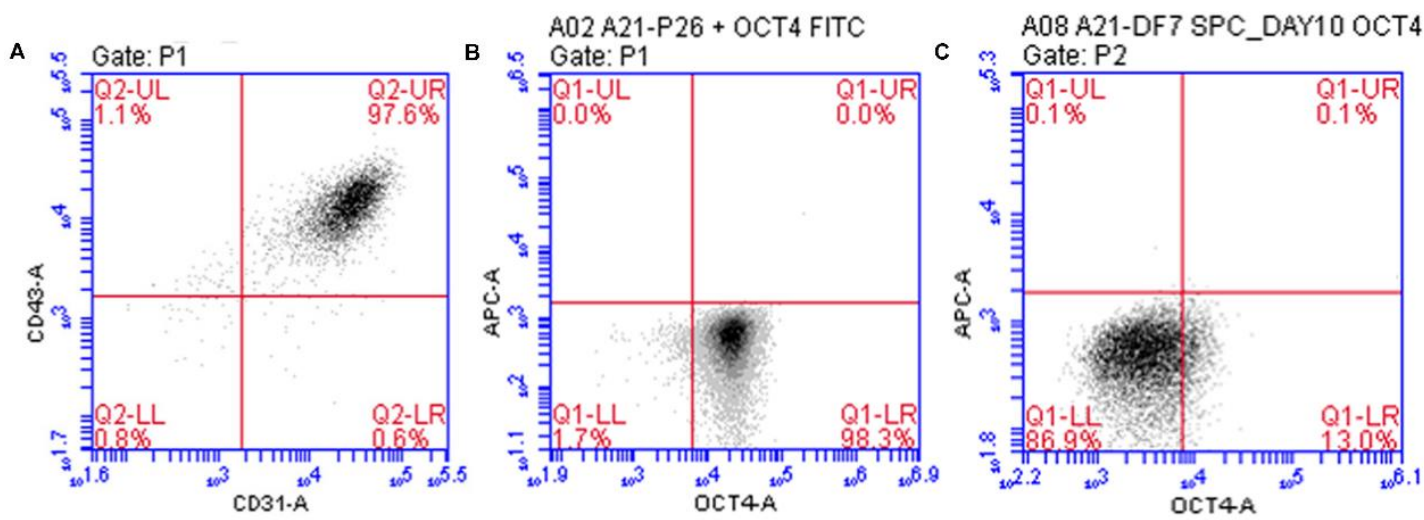

Figure S20. (A) CD31 and CD43 expression of human iPS-derived HPCs. OCT4 expression in (B) human iPSCs and (C) human iPS-derived HPCs. 


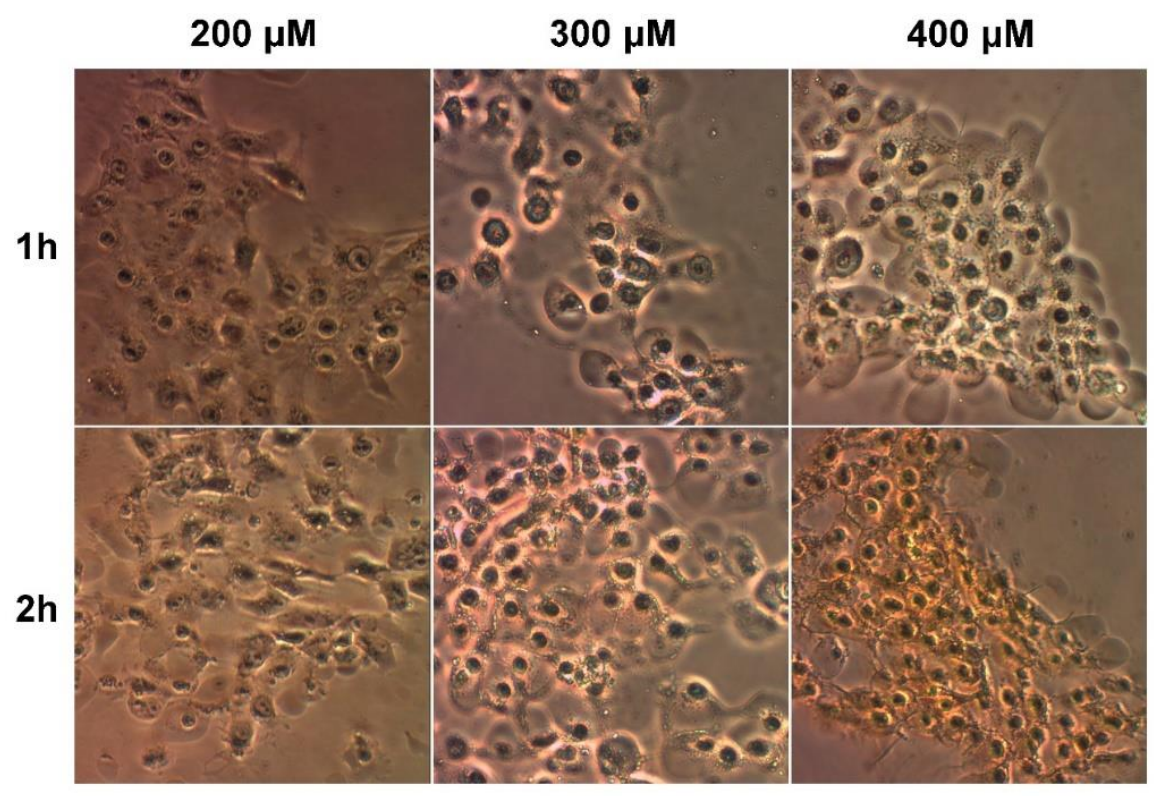

Figure S21. Optical photos of iPSCs after incubating with $\mathbf{5}$.

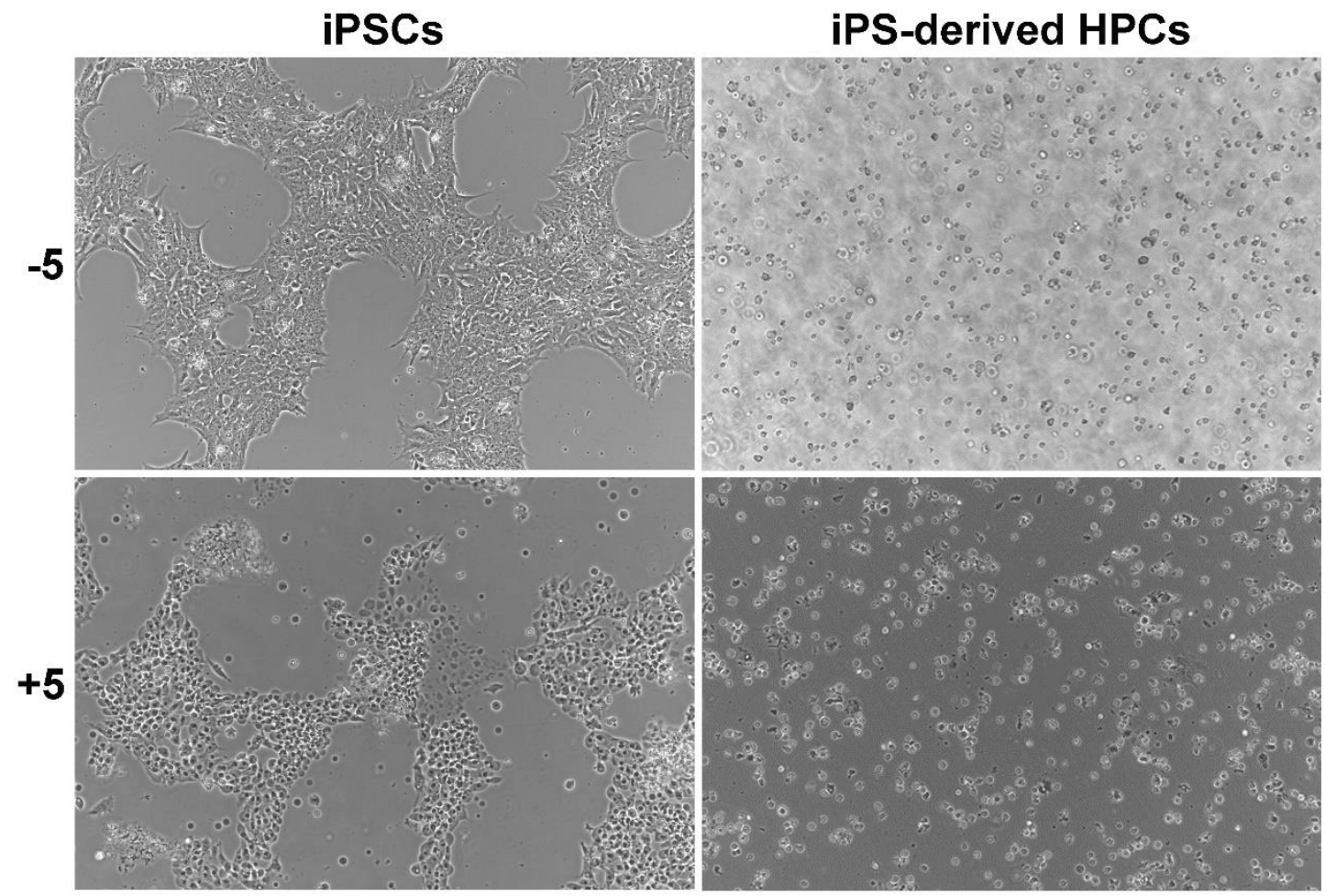

Figure S22. Optical images of iPSCs and iPS-derived HPCs before and after incubating with 5 (400 $\mu \mathrm{M})$ for $2 \mathrm{~h}$. 


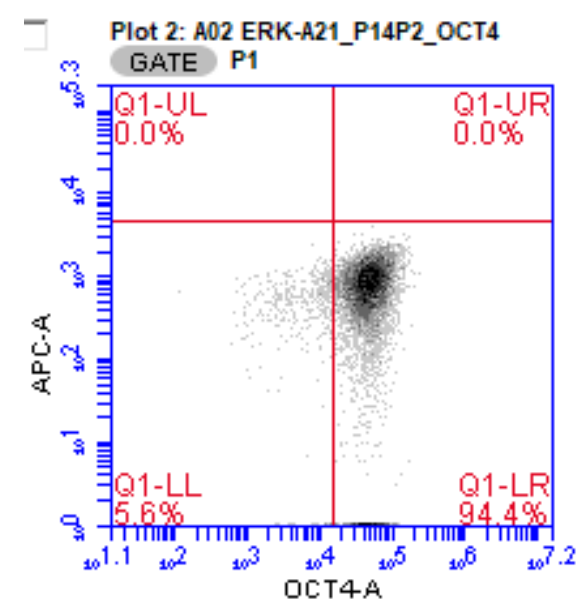

Figure S23. OCT4 expression in human iPSCs derived from A21.

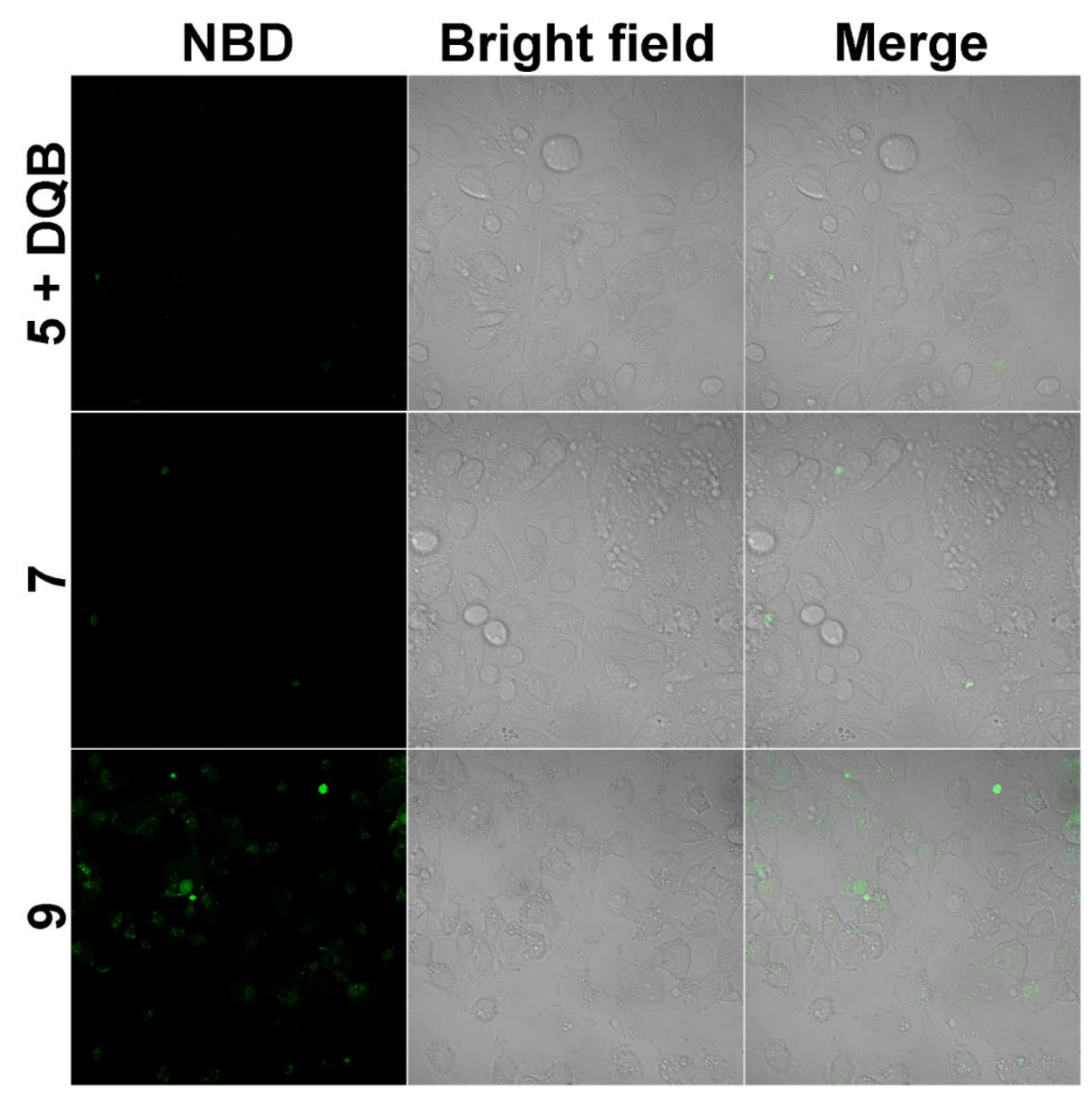

Figure S24. Confocal laser scanning microscopy (CLSM) images of iPS cells after being treated by $5(400 \mu \mathrm{M})$ with DQB $(5 \mu \mathrm{M}), 7(400 \mu \mathrm{M})$ or $9(400 \mu \mathrm{M})$ for $2 \mathrm{~h}$. 


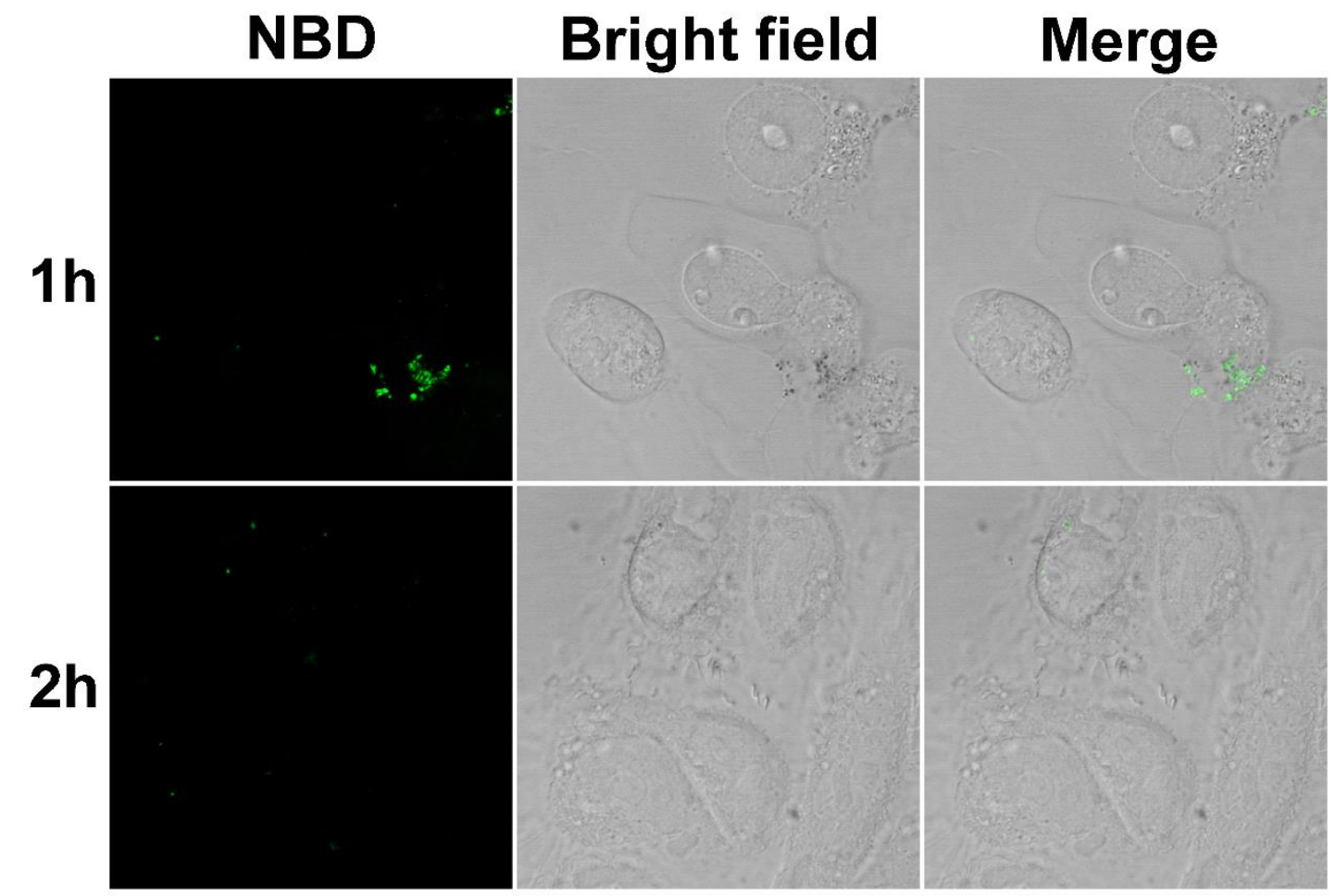

Figure S25. CLSM images of iPSCs after incubating with $\mathbf{5}(200 \mu \mathrm{M})$.

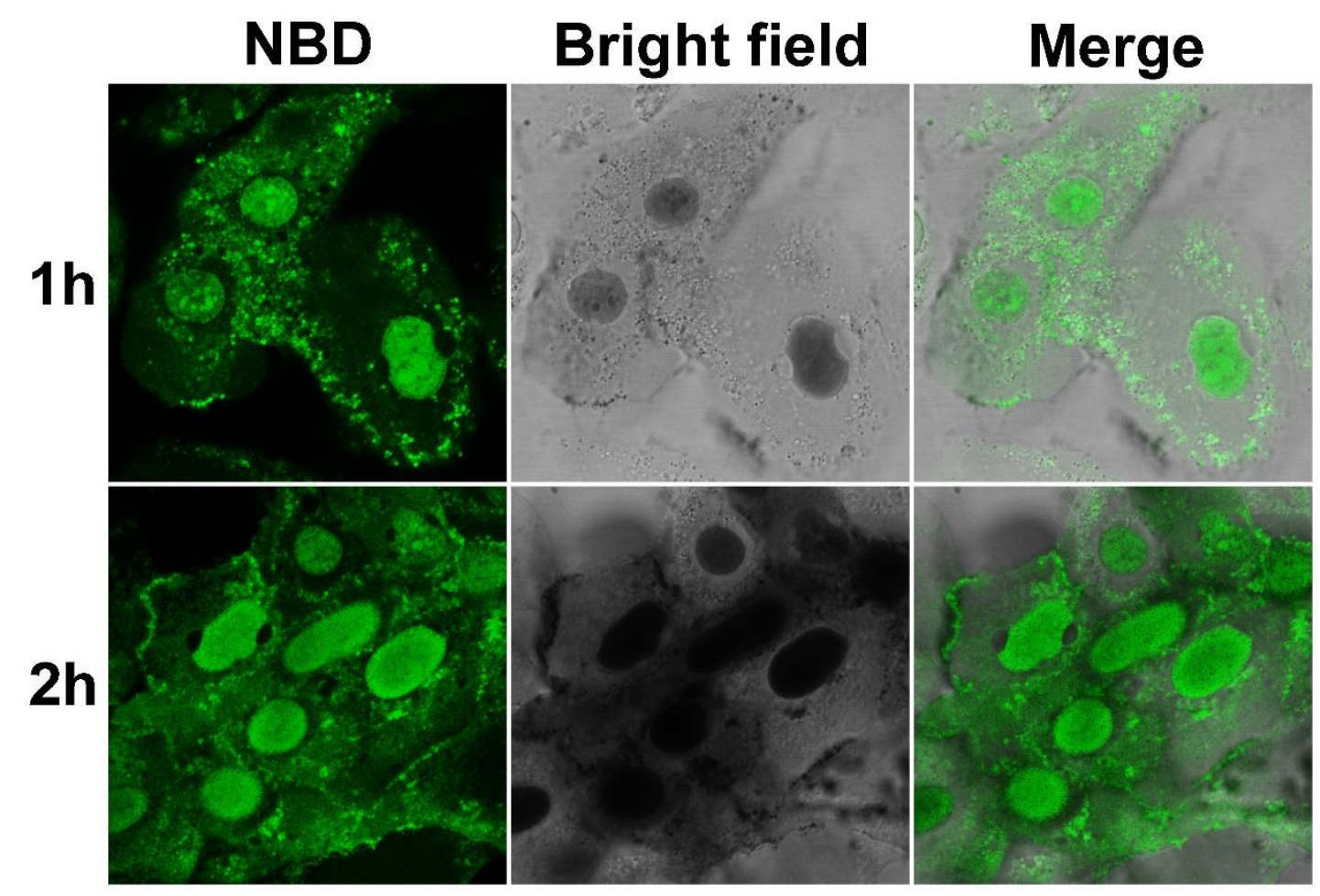

Figure S26. CLSM images of iPSCs after incubating with $\mathbf{5}(400 \mu \mathrm{M})$. 


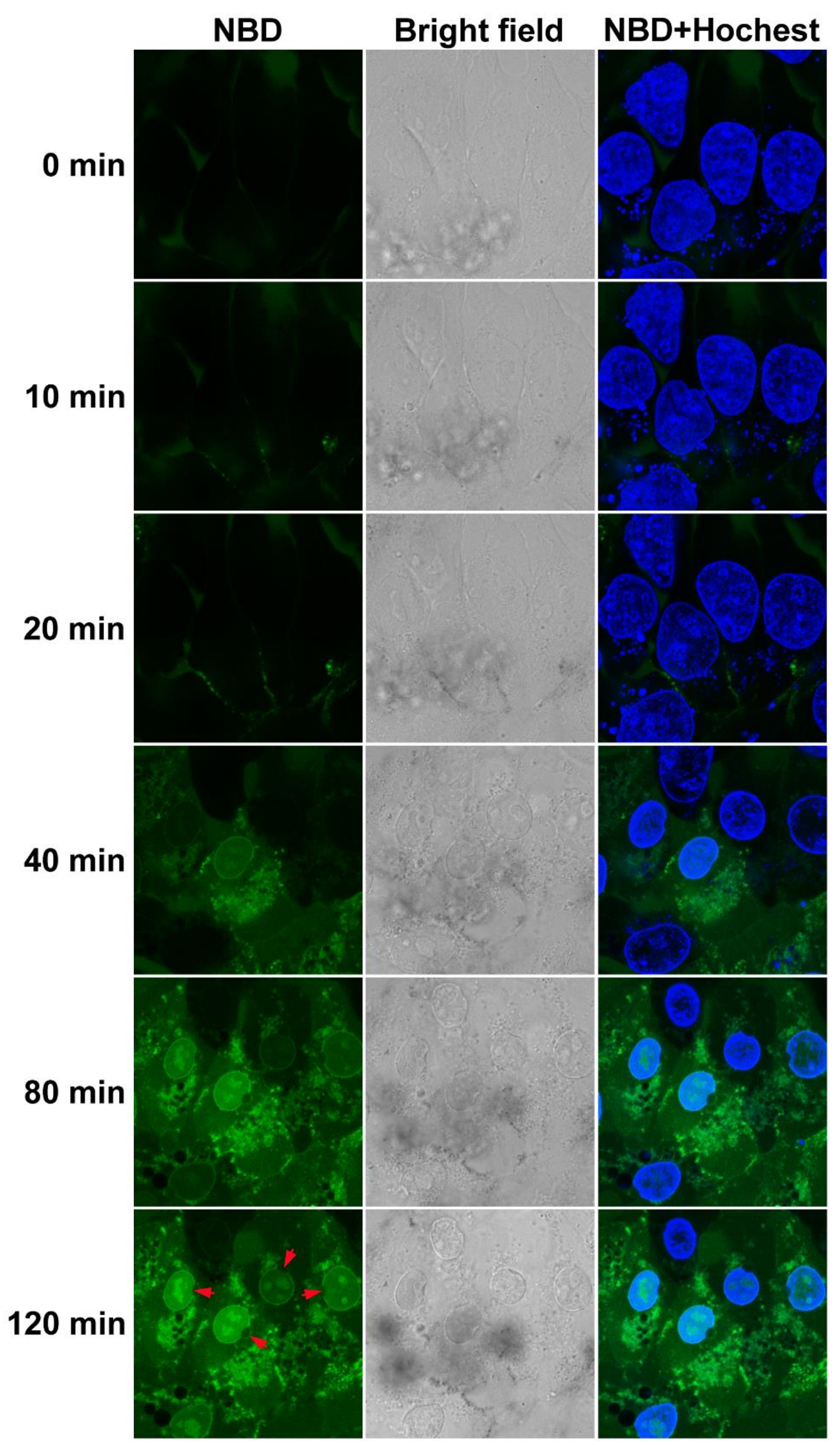

Figure S27. CLSM images of iPSCs after incubating with $5(400 \mu \mathrm{M})$ for different time, the red arrows show the disruption of nucleus membrane. 


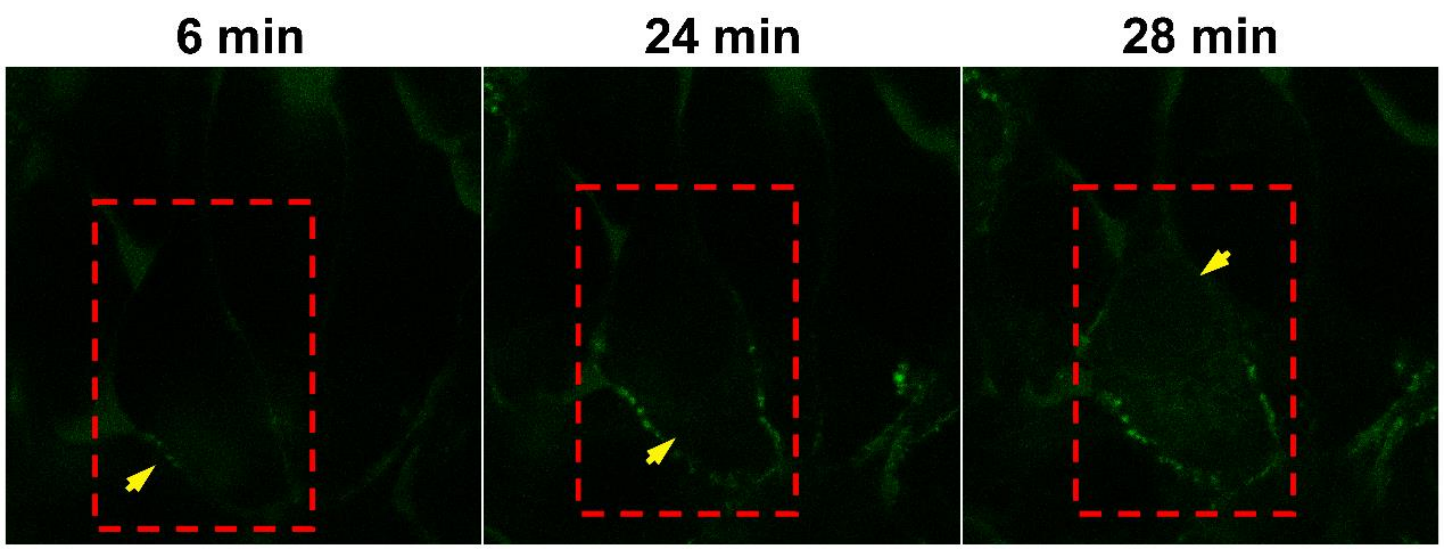

Figure S28. CLSM images of iPCs after incubating with $5(400 \mu \mathrm{M})$ for $6 \mathrm{~min}, 24 \mathrm{~min}$ and $28 \mathrm{~min}$. The red dash squares show the exampled cell. The yellow arrows show the fluorescent point on cell membrane, fluorescence in cytoplasm or nucleus.

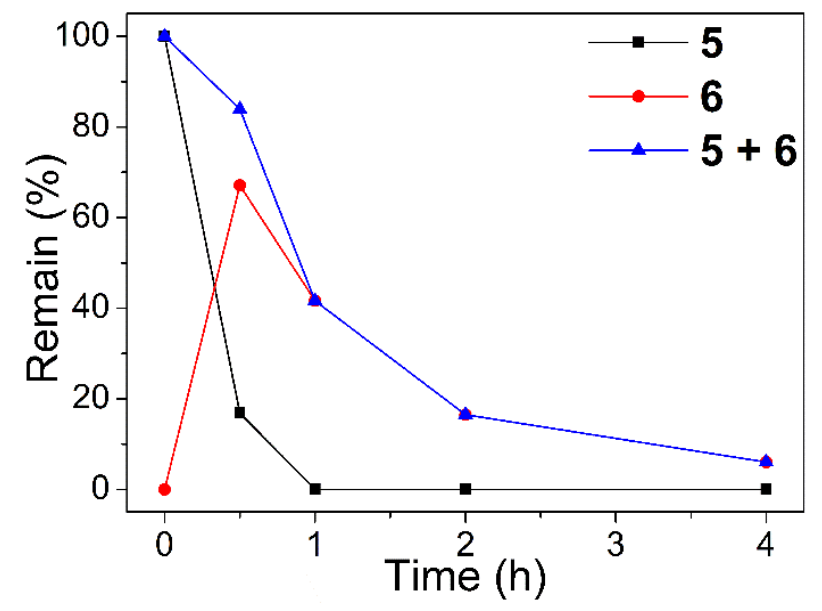

Figure S29. The remain percentages of 5 and $\mathbf{6}$ after 5 (200 $\mu$ M, PBS) being treated by HS-5 lysate (5 million cells in $1 \mathrm{~mL}$ ) for different time.

Table S3. LLLLY motif in the transmembrane domain of membrane proteins

\begin{tabular}{cccl}
\hline Gene & Uniprot & Starting position & \multicolumn{1}{l}{ Location } \\
& No. & of LLLLY & \\
\hline ABCA1 & O95477 & 1741 & endosome, cell membrane \\
\hline ABCA3 & Q99758 & 1158 & late endosome membrane, lysosome membrane \\
\hline ABCA7 & Q8IZY2 & 1622 & cell membrane, Golgi membrane, ruffle \\
& & & membrane, early endosome membrane
\end{tabular}




\begin{tabular}{|c|c|c|c|}
\hline ADCK2 & Q7Z695 & 113 & membrane \\
\hline ADCY9 & O60503 & 989 & cell membrane \\
\hline ATP13A3 & Q9H7F0 & 44 & $\begin{array}{l}\text { late endosome membrane, recycle endosome } \\
\text { membrane, early endosome membrane }\end{array}$ \\
\hline CSF1R & P07333 & 534 & cell membrane \\
\hline GOSR1 & O95249 & 243 & Golgi membrane \\
\hline GPR156 & Q8NFN8 & 234 & plasm membrane \\
\hline GPR18 & Q14330 & 156 & cell membrane \\
\hline ICMT & O60725 & 104 & endoplasmic reticulum membrane \\
\hline KCNS2 & Q9ULS6 & 329 & plasm membrane \\
\hline MFSD9 & Q8NBP5 & 364 & membrane \\
\hline PHTF1 & Q9UMS5 & 103 & $\begin{array}{l}\text { endoplasmic reticulum membrane, cell } \\
\text { membrane }\end{array}$ \\
\hline PIGZ & Q86VD9 & 370 & endoplasmic reticulum membrane \\
\hline SPATA31E1 & Q6ZUB1 & 81 & membrane \\
\hline SPPL2A & Q8TCT8 & 344 & late endosome membrane, lysosome membrane \\
\hline TSPO2 & Q5TGU0 & 110 & $\begin{array}{l}\text { endoplasmic reticulum membrane, cell } \\
\text { membrane }\end{array}$ \\
\hline
\end{tabular}

\section{Reference}

1. Feng, Q.; Zhang, M.; and Lu, S., Methods and systems for manufacturing hematopoietic linage cells. PCT/US2019/057929, WIPO PCT WO 2020/086889 A1. 